\title{
Article
}

\section{An atlas of anionic antimicrobial peptides from amphibians}

Dennison, Sarah Rachel, Harris, Frederick, Mura, Manuela and Phoenix, David A.

Available at https://clok.uclan.ac.uk/21764/

Dennison, Sarah Rachel orcid iconORCID: 0000-0003-4863-9607, Harris, Frederick, Mura, Manuela and Phoenix, David A. (2018) An atlas of anionic antimicrobial peptides from amphibians. Current Protein \& Peptide Science, 19. ISSN 1389-2037

It is advisable to refer to the publisher's version if you intend to cite from the work. http://dx.doi.org/10.2174/1389203719666180226155035

For more information about UCLan's research in this area go to http://www.uclan.ac.uk/researchgroups/ and search for <name of research Group>.

For information about Research generally at UCLan please go to http://www.uclan.ac.uk/research/

All outputs in CLoK are protected by Intellectual Property Rights law, including Copyright law. Copyright, IPR and Moral Rights for the works on this site are retained by the individual authors and/or other copyright owners. Terms and conditions for use of this material are defined in the policies page.

\section{CLoK}

Central Lancashire online Knowledge www.clok.uclan.ac.uk

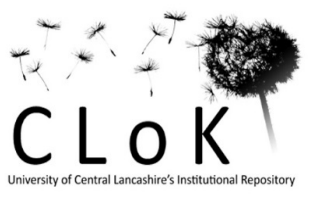




\title{
An atlas of anionic antimicrobial peptides from amphibians
}

\author{
Sarah R. Dennison ${ }^{a}$, Frederick Harris ${ }^{b}$, Manuela Mura ${ }^{\mathrm{c}}$ and David A. Phoenix ${ }^{\mathrm{d}^{*}}$
}

\begin{abstract}
${ }^{a}$ School of Pharmacy and Biomedical Sciences, University of Central Lancashire, Preston PRI $2 H E, U K ;{ }^{b}$ School of Forensic and Investigative Science, University of Central Lancashire Preston PRI 2HE, UK; ${ }^{c}$ School of Mathematics and Physics, University of Lincoln, Brayford Pool, Lincoln, LN6 7TS, UK; ${ }^{d}$ Office of the Vice Chancellor, London South Bank University, 103 Borough Road, London SEI OAA, UK;
\end{abstract}

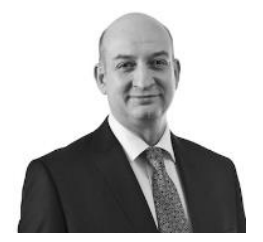

\begin{abstract}
Anionic antimicrobial peptides (AAMPs) with net charges ranging from -1 to -8 have been identified in frogs, toads, newts and salamanders across Africa, South America and China. Most of these peptides show antibacterial activity and a number of them are multifunctional, variously showing antifungal activity, anticancer action, neuropeptide function and the ability to potentiate conventional antibiotics. Antimicrobial mechanisms proposed for these AAMPs, include toroidal pore formation and the Shai-Huang-Matsazuki model of membrane interaction along with $\mathrm{pH}$ dependent amyloidogenesis and membranolysis via tilted peptide formation. The potential for therapeutic and biotechnical application of these AAMPs has been demonstrated, including the development of amyloid-based nanomaterials and antiviral agents. It is concluded that amphibian AAMPs represent an untapped potential source of biologically active agents and merit far greater research interest.
\end{abstract}

Keywords: Anionic antimicrobial peptides; amphibian; amyloid; amyloidogenesis; anticancer; membranolysis.

*Address correspondence to this author at the Office of the Vice Chancellor, London South Bank University, 103 Borough Road, London SE1 0AA, UK; Tel/Fax: +44 (0) 207815 6001; E-mails: phoenixd@1sbu.ac.uk

\section{INTRODUCTION}

Over the centuries, skin extracts from frogs and toads have been used as traditional medicine in many cultures ranging from that of ancient Egypt to China [1]. For example, Chan Su is derived from the dried skin and venom gland secretions of toads from the Bufo genus and is used in Chinese traditional medicines as a remedy for numerous conditions [2]. The earliest recorded use of this preparation appears to be in the Tang Dynasty (618 to $907 \mathrm{AD}$ ), and it is now known that the major active ingredients in Chan Su are bufadienolides, which are steroids or cardiac glycosides [3]. It is also now known that a wide variety of bioactive compounds are found in the skin secretions of amphibians [4], including peptides, ranging from those with myotropical and antioxidant properties to those with antimicrobial and anticancer activity (Table 1) [5-6]. Many of these peptides are pleiotropic. For example, some antimicrobial peptides (AMPs) exhibit antibacterial, antifungal, antiviral and anticancer action [7-8]. Amphibian skin is a particularly rich repository of AMPs [5-6] and was the source of one of the first of these peptides to be discovered, namely magainin from Xenopus laevis in the early 1980s [9]. Homologues of magainin have since been identified in other species of the Xenopodinae and studies on the phylogenic and evolutionary relationships between amphibian AMPs have estimated that the ancestral genes of these peptides may be up to around 200 million years old [10-11]. Indeed, it is now generally accepted that AMPs are ancient endogenous components of the innate immune system and exert their antimicrobial activity via membrane interactions that involve relatively non-specific mechanisms at multiple sites of action [12]. Microbes appear to have a limited capacity to defend themselves against this multi-faceted activity with the result that the resistance of these organisms to AMPs has a low incidence and is generally due to inherent rather than adaptive mechanisms [13-14]. It has been proposed that these observations may help explain the fact that these peptides have maintained their efficacy over evolutionary time and led to the generally held view that microbial resistance to AMPs is unlikely to approach that shown by these organisms to conventional antibiotics [15-16]. This gives AMPs a major medical advantage over other antimicrobials and makes them attractive propositions to combat the global problem of infectious diseases due to drug resistant microbial pathogens [17-18]. In this capacity, a number of these peptides have been trialled in clinical regimes [1920], including magainin in the form of pexiganan for the treatment of diabetic foot infections and ulcers [21]. 
Table 1. Major bioactive peptides found in the secretions of amphibian skin. Table 1 was compiled from Xu and Lai [5].

\begin{tabular}{ll}
\hline Myotropical peptides & Wound-healing peptides \\
Opioid peptides & Immunomodulatory peptides \\
Corticotropin- releasing & Neuronal nitric oxide synthase \\
peptides & inhibitors \\
Angiotensins & Antibacterial peptides \\
Protease inhibitor peptides & Antifungal peptides \\
Neuropeptides & Antiviral peptides \\
Antioxidant peptides & Antiparasitic peptides \\
Lectins & Anticancer peptides \\
Insulin releasing peptides & Pheromone peptides \\
Mast cells degradation / & Granains \\
histamine-releasing peptides & \\
\hline
\end{tabular}

The vast majority of AMPs so far reported [22], including those in clinical trials [19-21], are cationic (CAMPs), which is likely to be an evolutionary adaptation that allows these peptides to target and interact with anionic components of microbial membranes [23-24]. In general, these interactions are an early step in the antimicrobial mechanisms of these AMPs, and this type of interaction leads to the disruption of membranes or translocation of the peptides across membranes to utilise intracellular sites of action [12, 24-25]. However, a growing number of anionic AMPs (AAMPs) are also being reported [26$30]$ and some of the most prolific producers of these peptides are amphibians (Tables $2 \& 3$ ). Currently, these amphibians have been identified across three continents and here, we review the AAMPs produced by these organisms in relation to their antimicrobial activity and other biological roles (Table 4).

\section{AMPHIBIAN AAMPS FROM AFRICA AND SOUTH AMERICA}

More commonly known as the African clawed frog, X. laevis, is native to sub-Saharan Africa, and currently, this amphibian is the most prolific, known producer of AAMPs with three of the these peptides credited to its antimicrobial arsenal [31-33]. In 1997, PYL (net charge -5) was isolated from X. laevis, making this the first major example of an AAMP to be reported. Characterisation of PYL showed it to be a sequence of homopolymeric aspartate residues with weak $\mathrm{Zn}^{2+}$ mediated activity against Gram-positive bacteria, such as Serratia marcescens, and Gram-negative bacteria, including Pasteurella haemolytica [31]. Interestingly, this work earned X. laevis a central position in the history of AMPs in that it was the first eukaryotic host shown to produce both AAMPs and CAMPs [10-11], although the amphibian is now, perhaps better known for its world-wide invasive presence, primarily due to its global use as a model organism [34]. More recently, XLAsp-P1 (net charge -5) was identified in the skin of $X$. laevis, which in contrast to PYL, showed antibacterial activity that did not appear to require the presence of $\mathrm{Zn}^{2+}$ ions. The peptide exhibited activity against Gram-negative bacteria, such as Aeruginosus bacillus, and Grampositive organisms, including Aerococcus viridians, which appeared to involve a membranolytic mode of action that resembled a toroidal pore type mechanism [33]. Most recently, a peptide, designated XLAsp-P2 (net charge -5), was also identified in the skin of X. laevis, which showed activity against the fungus, Candida albicans, Gram-negative bacteria, such as Escherichia coli, and in particular, Gram-positive bacteria, including Staphylococcus aureus and its chloramphenicol resistant strain, RN4200. Mechanisms underpinning the antibacterial activity of the peptide were investigated and appeared to primarily involve membrane disruption, which was accompanied by attack on the DNA of these organisms [32]. These observations are consistent with the use of the Shai-Huang-Matsazuki (SHM) model of membrane interaction, which is a variant of the carpet mechanism that accommodates multiple sites of action and has previously been reported for AAMPs [27]. Studies on XLAspP2 also showed that the peptide acted against $S$. aureus RN4200 and some E. coli strains in an additive manner with conventional antibiotics, such as the aminoglycoside, kanamycin, and the $\beta$-lactam, ampicillin [32]. This would appear to be one of the first reports of amphibian AAMPs potentiating the activity of conventional antibiotics, although this ability has been demonstrated for CAMPs from these organisms. For example, magainins and $\beta$-lactams were found to show synergistic activity against oxacillin-resistant $S$. aureus [51]. Interestingly, both XLAsp-P2 and XLAsp-P1 showed high levels of homology to PYL, also possessing aspartate rich regions (Table 2), and the primary role of the latter peptide is as the activation peptide of the PYL hormone found in X. laevis, inviting the speculation that the former two AAMPs may have similar multiple functionality $[31,33]$. 
Table 2. AAMPs from amphibians.

\begin{tabular}{|c|c|c|c|}
\hline AAMPs & Sequence & $\begin{array}{c}\text { Host } \\
\text { amphibian }\end{array}$ & $\begin{array}{c}\text { Key } \\
\text { references }\end{array}$ \\
\hline $\mathrm{He}-1$ & $\begin{array}{l}\text { DDDKTEE } \\
\text { EDDKENE } \\
\text { TTKVVE }\end{array}$ & Hyla eximia & [35] \\
\hline Thaulin-4 & $\begin{array}{l}\text { DDGEEAE } \\
\text { SEAANPE } \\
\text { ENTVGG }\end{array}$ & $\begin{array}{c}\text { Pleurodema } \\
\text { thaul }\end{array}$ & [36] \\
\hline Octacidin & $\begin{array}{l}\text { DSVASSA } \\
\text { AQELSGV } \\
\text { LASN }\end{array}$ & $\begin{array}{l}\text { Osteocephalus } \\
\text { taurinus }\end{array}$ & [37] \\
\hline $\begin{array}{l}\text { Pleurain- } \\
\text { C1 }\end{array}$ & $\begin{array}{l}\text { YPELQQD } \\
\text { LIARLL }\end{array}$ & $\begin{array}{c}\text { Rana } \\
\text { pleuraden }\end{array}$ & [38] \\
\hline $\begin{array}{l}\text { Pleurain- } \\
\quad \text { C2 }\end{array}$ & $\begin{array}{l}\text { FPELQQD } \\
\text { LIARLL }\end{array}$ & $\begin{array}{c}\text { Rana } \\
\text { pleuraden }\end{array}$ & [38] \\
\hline $\begin{array}{l}\text { Brevinin- } \\
\text { 1-AJ3 }\end{array}$ & $\begin{array}{l}\text { FLPLAVSL } \\
\text { AANFLPK } \\
\text { LFCKITKN } \\
\text { VETLEME } \\
\text { LEII }\end{array}$ & $\begin{array}{c}\text { Amolops } \\
\text { jingdongensis }\end{array}$ & [39] \\
\hline $\begin{array}{l}\text { Jingdongi } \\
\mathrm{n}-2\end{array}$ & $\begin{array}{l}\text { FLPIVENC } \\
\text { SLVCWEN } \\
\text { NQKC }\end{array}$ & $\begin{array}{c}\text { Amolops } \\
\text { jingdongensis }\end{array}$ & [39] \\
\hline PopuDef & $\begin{array}{l}\text { GASPALW } \\
\text { GCDSFLG } \\
\text { YCRIACFA } \\
\text { HEASVGQ } \\
\text { KDCAEGM } \\
\text { ICCLPNVF }\end{array}$ & $\begin{array}{c}\text { Polypedates } \\
\text { puerensis, }\end{array}$ & [40] \\
\hline $\begin{array}{l}\text { Defensin- } \\
\text { TK }\end{array}$ & $\begin{array}{l}\text { SPAIWGC } \\
\text { DSFLGYC } \\
\text { RLACFAH } \\
\text { EASVGQK } \\
\text { ECAEGML } \\
\text { CCIPNVF }\end{array}$ & $\begin{array}{l}\text { Theloderma } \\
\text { kwangsiensis }\end{array}$ & [41] \\
\hline CFBD-1 & $\begin{array}{l}\text { FAVWGCA } \\
\text { DYRGYCR } \\
\text { AACFAFE } \\
\text { YSLGPKG } \\
\text { CTEGYVC } \\
\text { CVPNTF }\end{array}$ & $\begin{array}{c}\text { Cynops } \\
\text { fudingensis }\end{array}$ & [42] \\
\hline PYL & $\begin{array}{l}\text { ADADDDD } \\
\text { DK }\end{array}$ & Xenopus laevis & [31] \\
\hline $\begin{array}{l}\text { XLAsp- } \\
\text { P1 }\end{array}$ & DEDDD & Xenopus laevis & {$[33]$} \\
\hline $\begin{array}{l}\text { XLAsp- } \\
\text { P2 }\end{array}$ & DEDLDE & Xenopus laevis & [32] \\
\hline PD-3-7 & $\begin{array}{l}\text { LLGDLLG } \\
\text { QTSKLVN } \\
\text { DLTDTVG } \\
\text { SIV }\end{array}$ & $\begin{array}{l}\text { Pachymedusa } \\
\text { dacnicolor }\end{array}$ & [43] \\
\hline $\begin{array}{l}\text { Maximin } \\
\text { H5 }\end{array}$ & $\begin{array}{l}\text { ILGPVLGL } \\
\text { VSDTLDD } \\
\text { VLGIL- } \\
\mathrm{NH}_{2}\end{array}$ & $\begin{array}{c}\text { Bombina } \\
\text { maxima }\end{array}$ & [44] \\
\hline
\end{tabular}


Table 3. Peptide B / enkelytin from amphibians. Table 3 shows the sequences of peptide B / enkelytin, which are encrypted within proenkephalin (PENK) of a variety of amphibians. Also shown are the SwissProt accession codes for these sequences, which are available at the SwissProt database, (http://web.expasy.org/docs/swiss-prot).

\begin{tabular}{|c|c|c|}
\hline $\begin{array}{c}\text { Host } \\
\text { amphibian }\end{array}$ & Sequence & $\begin{array}{l}\text { Key references } \\
\text { and SwissProt } \\
\text { accession code }\end{array}$ \\
\hline $\begin{array}{c}\text { Amphiuma } \\
\text { means } \\
\text { (Salamander) }\end{array}$ & $\begin{array}{l}\text { FTDYSAPSDEDGESYS } \\
\text { KEIPEMEKRYGGFMRF }\end{array}$ & $\begin{array}{c}\text { [45] } \\
\text { Q6YIR4 }\end{array}$ \\
\hline $\begin{array}{c}\text { Necturus } \\
\text { maculosus } \\
\text { (Salamander) }\end{array}$ & $\begin{array}{l}\text { FADYSAPSDEDGESYS } \\
\text { KEIPEMEKRYGGFMRI }\end{array}$ & $\begin{array}{c}{[45]} \\
\text { Q6YIR3 }\end{array}$ \\
\hline $\begin{array}{l}\text { Taricha } \\
\text { granulose } \\
\text { (Newt) }\end{array}$ & $\begin{array}{c}\text { FADSSAPSEEEAESYSK } \\
\text { EIPEMEKRYGGFMRY }\end{array}$ & $\begin{array}{c}{[46]} \\
\text { Q5PZ00 }\end{array}$ \\
\hline $\begin{array}{l}\text { Xenopus } \\
\text { laevis } \\
\text { (Frog) }\end{array}$ & $\begin{array}{l}\text { FTDSFLPSDEDGESYSK } \\
\text { ENPDMEKRYGGFMRF }\end{array}$ & $\begin{array}{c}{[47]} \\
\mathrm{P} 01212\end{array}$ \\
\hline $\begin{array}{c}\text { Xenopus } \\
\text { tropicalis } \\
\text { (Frog) }\end{array}$ & $\begin{array}{l}\text { FTDSFLPSEEDGESYSK } \\
\text { ENPDMEKRYGGFMRF }\end{array}$ & $\begin{array}{c}{[48]} \\
\text { F6Y5F6 }\end{array}$ \\
\hline $\begin{array}{c}\text { Bombina } \\
\text { orientalis } \\
\text { (Toad) }\end{array}$ & $\begin{array}{l}\text { FADSLLPSDEDGESYS } \\
\text { KEVPEVEKRYGGFMRF }\end{array}$ & $\begin{array}{c}{[49]} \\
\text { Q5Y4B6 }\end{array}$ \\
\hline $\begin{array}{c}\text { Spea } \\
\text { multiplicatus } \\
\text { (Toad) }\end{array}$ & $\begin{array}{l}\text { FSDSVLPSDEDGESYSK } \\
\text { EIPEMDKRYGGFMRF }\end{array}$ & $\begin{array}{c}{[50]} \\
\text { Q9I817 }\end{array}$ \\
\hline
\end{tabular}

Table 4. AAMPs from amphibians and their biological activities.

\begin{tabular}{|c|c|c|c|c|c|}
\hline AAMPs & $\begin{array}{c}\text { Anti- } \\
\text { bacterial }\end{array}$ & $\begin{array}{l}\text { Anti- } \\
\text { fungal }\end{array}$ & Anti-cancer & Other activities & Key references \\
\hline $\mathrm{He}-1$ & - & NT & NT & NT & [35] \\
\hline Thaulin-4 & - & NT & NT & NT & [36] \\
\hline Octacidin & + & NT & NT & NT & [37] \\
\hline Pleurain-C1 & + & + & NT & NT & [38] \\
\hline Pleurain-C2 & NT & NT & NT & NT & [38] \\
\hline Brevinin-1-AJ3 & NT & NT & NT & NT & [39] \\
\hline Jingdongin-2 & - & - & NT & NT & [39] \\
\hline PopuDef & + & NT & NT & NT & [40] \\
\hline Defensin-TK & + & + & NT & NT & [41] \\
\hline CFBD-1 & + & + & NT & NT & {$[42]$} \\
\hline PYL & + & _ & _ & Propeptide & [31] \\
\hline XLAsp-P1 & + & NT & + & Propeptide & [33] \\
\hline XLAsp-P2 & + & + & NT & Propeptide & [32] \\
\hline PD-3-7 & _ & NT & NT & Insecticidal & [52-53] \\
\hline Maximin H5 & + & & + & Neuropeptide & {$[44,54-56]$} \\
\hline
\end{tabular}


A number of AAMPs have been reported from South America, including those with the highest levels of negative charge: for example, almost a decade ago, he-1 with a net charge of -8 was identified in the Mountain tree frog, Hyla eximia, which is endemic to Mexico [35]. Most recently, thaulin-4, which also has a net charge -8, was isolated from the Chilean four-eyed frog, Pleurodema thaul, which is widely distributed in Argentina and Chile [36]. In contrast, the Manaus slender-legged tree frog, Osteocephalus taurinus, native to many parts of South America and was found to produce octacidin (net charge -2) in its skin secretions. The peptide was predicted to form $\alpha$-helical secondary structure and exhibited potent activity against a variety of Gram-negative bacteria, including Escherichia coli and Pseudomonas aeruginosa [37]. However, the most studied amphibian producer of AAMPs from South America would appear to be the Mexican giant tree frog, Pachymedusa dacnicolor, which is native to Southern Mexico, a number of dermaseptins have been identified in the amphibian [57]. Studies on the skin of $P$. dacnicolor led to the description of the AAMP, dermaseptin PD-3-7 (net charge -3), which was classified as an 'orphan' dermaseptin, but was not investigated for antimicrobial activity [43]. The dermaseptins are a superfamily of AMPs that can be divided into seven subfamilies and 'orphan' dermaseptins form a group whose members do not resemble those of the remaining subfamilies [58]. More recent studies on PD-3-7 showed that the peptide had an inherent propensity to adopt an extended conformation in aqueous solution and self-assemble in a reversible $\mathrm{pH}$-controlled fashion to form amyloid fibrils [52], which is now generally regarded as a unique protein quaternary structure [59]. It was demonstrated that PD-3-7 existed as amyloid-like $\beta$-sheet aggregates at low $\mathrm{pH}$ but increasing $\mathrm{pH}$ led the peptide to undergo morphological changes, which were mediated by deprotonation of the aspartic acid residues and C-terminal carboxyl groups possessed by the peptide. These morphological changes led to the formation of metastable amorphous aggregates at high $\mathrm{pH}$, which had no effect against E. coli and Bacillus subtilis but induced damage on cells of the insect, Spodoptera frugiperda [52]. The mechanism underpinning the activity of PD-3-7 against $S$. frugiperda was not elucidated, but it is known that AAMPs with amyloid-mediated modes of membrane interaction show activity against eukaryotic cells [12, 60-61], including fungi [62-63] and neurones [64-65].

More recent studies on amphibian L/D-isomerases suggested that $P$. dacnicolor produced PD-3-7 as epimers, which differ by the stereochemical modification, L-Leu2 $\rightarrow$ d-Leu2 [66]. It is well established that epimeric AMPs are produced by amphibians [5], such as the Polka-dot tree frog, Hypsiboas punctatus [67], which produces phenylseptins. Previous studies have suggested that the production of epimeric AAMPs is a strategy used to enhance the antimicrobial efficacy of some frogs and toads [26]. Studies that are more recent showed that the stereochemical modification, L-Leu2 $\rightarrow$ d-Leu2, strongly influenced the pH-triggered, morphological changes involved in amyloid formation by the PD-3-7 [53]. These morphological changes showed many similarities to those observed in amyloid formation by epimeric peptides from platypus venom [68-69] and $A \beta 42$ and $A \beta 40$, which appear to act as AAMPs in innate defence of the brain [60,62-63]. In particular, the response of PD-3-7 epimers to changes in $\mathrm{pH}$ led to differences in their super structural organisation, which were related to the differing conformational propensities of these peptides [53]. Similar differences in folding propensity under conditions that promote selfaggregation have also been reported for bombinins $\mathrm{H} 2$ and $\mathrm{H} 4$, which are epimeric peptides from toads of the Bombina genus [70]. It has been proposed that these differences in folding ability may contribute to the higher levels of membrane perturbation and antimicrobial activity observed for bombinin $\mathrm{H} 4$, which contains the L-Leu2 $\rightarrow$ d-Leu2 substitution, as compared to bombinin H2 [71]. The biological activities of [d-Leu2] PD-3-7 was not determined, but it appeared that the N-terminal conformation of PD-3-7 epimers critically and differentially affected fibril twist and thus their resulting superstructures, which led to the speculation that d-Leu2 may act as a switch to control amyloid formation [53]. It is well established that dysregulated amyloid formation is detrimental to the host [72] and it has previously been suggested that amyloidogenesis by PD-3-7 may represent a storage facility for the peptide [52] similar to pituitary peptide hormones [73]. In this scenario, triggered by an increase in $\mathrm{pH}$, the PD-3-7 storage facility would release a preformed defence molecule that contributed to the innate immune system of $P$. dacnicolor [52].

\section{AMPHIBIAN AAMPS FROM CHINA}

Currently, the largest number of reported AAMPs from amphibians are those identified in China, such as the Yunnan pond frog, Rana pleuraden, (Babina pleuraden), which is native to South Western China and adjacent regions of Myanmar, and produces pleurain-C1 (net charge -1) and pleurain-C2 (net charge -1). These peptides differ by only a single residue at position $1(\mathrm{Y} \rightarrow \mathrm{F})$ and pleurain-C1 was found to possess both antibacterial activity, killing E. coli, S. aureus and Bacillus subtilis, and antifungal activity with action against $C$. albicans [38]. Two AAMPs were identified in the skin of the Chinese torrent frog, Amolops jingdongensis, which is also native to South Western China. These AAMPs were designated brevinin-1-AJ3 (net charge -1) and jingdongin-2 (net charge -1) [39]. The latter peptide along with the CAMP, jindongin-1, appeared to constitute a novel family of AMPs with no similarity to known amphibian peptides [5], but both peptides showed the potential to form a Cterminal cyclic region stabilised by a disulphide bond, Cys18-(Xaa) 4 -Lys-Cys24 (Table 2) [39], which is known as the 'Rana box' and is characteristic of AMPs from Ranid frogs [5-6]. The 'Rana box' is often associated with the antimicrobial activity of AMPs [74], but jingdongin-2 exhibited no activity against the panel of bacteria and fungi tested, although this panel was small [39]. Many brevinins form a 'Rana box' [5] and in the case of brevinin-1-AJ3, a sequence homologous to this motif, Cys18- 


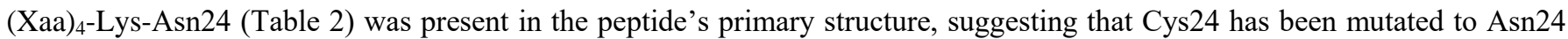
resulting in a loss of ability to form a 'Rana box' [39]. Brevinin-1-AJ3 was not characterised by the latter study and its properties remain unknown but many atypical brevinins with potent antimicrobial activity are known where the 'Rana box' of these peptides has either been lost or mutated [5, 75-77]. Brevinin-1-AJ3 and jingdongin-2 were also notable for the fact that they each contained a free half-cysteine residue [39], which is rare amongst AAMPs, evidenced by the small number of these peptides listed in the APD3 database [22]. These AAMPs have been identified in several sources [78] but most appear to be from plants [22], such as Cn-AMP3, which is one of several AAMPs found in the Coconut, Cocos nucifera [28, 79]. In general, the role of free cysteine residues in the activity of AMPs is unclear although recent work has suggested that these residues may play a role in facilitating peptide dimerization rather than directly promoting the antimicrobial activity of AMPs [80]. However, it is also interesting to note that an increasing number of multifunctional peptides are being identified in the skin of amphibians, both serving as AAMPs / CAMPs and possessing antioxidant activity, which is promoted by the presence of free half-cysteine residues [38, 81-82]. Indeed, a number of anionic antioxidant peptides have been reported that have yet to be tested for antimicrobial activity, such as andersonin-AOP1 (net charge -1) from Anderson's frog, Odorrana andersonii which is found in the Yunnan Province of China and regions of neighbouring countries [83]. The Puer tree frog, Polypedates puerensis (Rhacophorus puerensis), is primarily known in the Yunnan Province of China, and was recently shown to be the host of the first anionic defensin from amphibians, PopuDef (net charge -1). It was found that the expression of PopuDef was upregulated in immune related tissues of $P$. puerensis, such as the skin and gut, in response to bacterial challenge. The peptide showed moderate activity against organisms able to induce its expression, including Gram-negative bacteria, such as $P$. aeruginosa and Gram-positive bacteria, including B. subtilis [40]. Since the discovery of PopuDef, a second amphibian anionic defensin has been identified in skin secretions of the tree frog, Theloderma kwangsiensis (Theloderma kwangsiense), which is mostly found in Eastern Guangxi Province, China. Designated defensin-TK (net charge -1), the peptide showed broad range antimicrobial activity with efficacy against $C$. albicans, Gram-positive bacteria, such as $S$. aureus, and Gram-negative bacteria, including B. dysenteriae [41]. Our own analyses using the SIM - Alignment Tool for protein sequences (http://web.expasy.org/sim/) revealed that there is circa $90 \%$ sequence homology between defensin-TK and PopuDef. Given that these peptides have been identified in frogs from the same taxonomic family [84], this would suggest that defensin-TK and PopuDef may have originated from a common gene. Moreover, these latter two AAMPs showed homology of around 50\% with CFBD-1, which is a defensin from the fire-bellied newt, Cynops fudingensis, a new species recently identified in North Eastern Fujian Province, China [40-41]. This peptide was mildly anionic (net charge - 0.4) and showed moderate activity against Grampositive bacteria, such as $S$. aureus, and weaker activity against other bacteria and fungi [42].

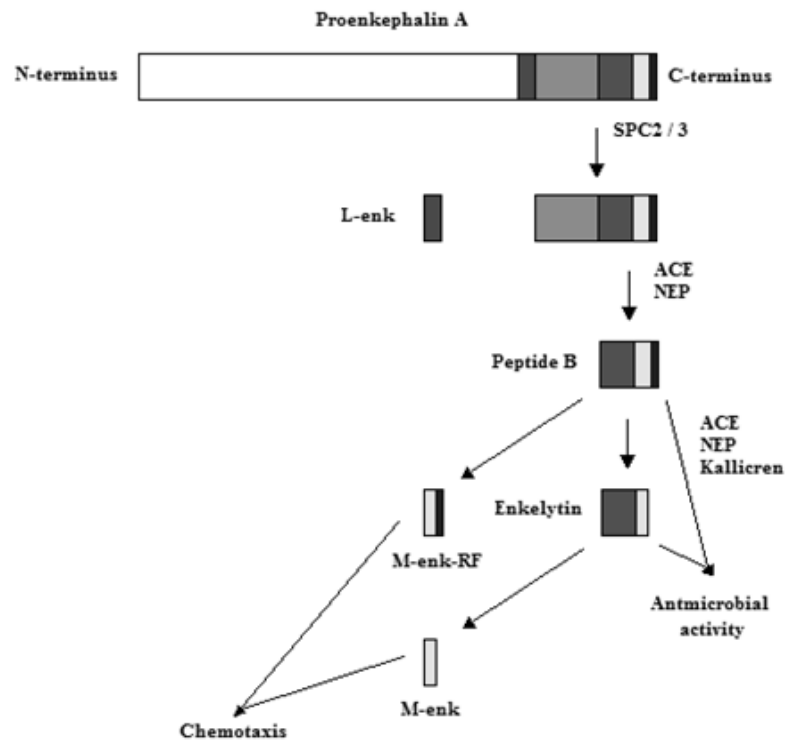

Figure 1. The processing of human proenkephalin A. Figure 1 was revised from [85-86] and shows a model for the processing of human proenkephalin (PENK) in response to microbial challenge. According to this model, the action of prohormoneconvertase 2 or 3 (SPC2/3) on the C-terminal region of PENK yields a segment containing peptide $\mathrm{B}$. This segment is then cleaved to peptide $\mathrm{B}$, which is then further fragmented by angiotensin converting enzyme (ACE) and neutral endopeptidase (NEP) to either enkelytin or M-enk-RF (Methionine-enkephalin-arginine-phenylalanine). Enkelytin is also degraded by ACE and NEP to M-enk (Methionine-enkaphalin). M-enk and M-enk-RF are opioid peptides and induce 
chemotaxis whilst peptide B and enkelytin engage in antibacterial activity [85-86]. This strategy contrasts with that used by maximin H5 and homologous AAMPs in the brains of B. maxima and B. microdeladigitora where antimicrobial and neuropeptide capability appear to be localised within single molecules [87].

CFBD-1 would appear to be the first AAMP to be characterised in salamanders, although evidence has been previously presented, which infers the presence of other AAMPs in the brains of these organisms (Table 3) [26]. In human brains, it is believed that peptide B (net charge -6) and its truncated form, enkelytin (net charge -7), are enzymatically cleaved from the opioid hormone, proenkephalin (PENK), in response shown to microbial challenge [85-86]. PENK processing to produce these AAMPs also generates opioid peptides and it is believed that this strategy helps provide an immediate, coordinated innate immune response to the threat of infection (Fig. 1) [26, 86]. PENK is highly conserved across the eukaryotic kingdom, and homologues of peptide B / enkelytin are encrypted within the sequence of this opioid hormone in a number of amphibians, as revealed by a search of the SwissProt database (http://web.expasy.org/docs/swiss-prot). Examples include salamanders, newts, frogs and toads, which strongly suggests that these AAMPs are present in the brains of organisms across Amphibia (Table 3). Recently, the PENK related potential to produce peptide B / enkelytin was reported for the Western clawed frog, Xenopus tropicalis (Silurana tropicalis), which is found in the West African rainforest belt and is closely related to X. laevis (Table 3) [48]. As a matter of historical interest, the PENK related potential to produce peptide B / enkelytin was identified in the latter organism over five years before it was shown to be the host of PYL, the first of demonstrated amphibian AAMPs [47].

The Yunnan firebelly toad, Bombina maxima, is native to the mountainous regions of South Western China and adjacent Northern Vietnam, and the skin secretions of the frog have been found to include maximin H5 (net charge - 1) [44], which is probably the best characterised of amphibian AAMPs [29, 54, 87-90]. A number of characterisation studies have shown that maximin $\mathrm{H} 5$ is a predominantly $\alpha$-helical peptide with multiple biological roles, which are described below, and include: antibacterial action [44, 54, 89], anticancer activity [29, 55] and neuropeptide functions [56].

\subsection{The neuropeptide function of maximin $\mathrm{H5}$}

Phylogenetic studies have shown that maximin H5 and homologous AAMPs belong to a suite of AMPs that has arisen through rapid gene diversification, driven by positive selection. These are present in the brains of $B$. maxima and the Hubei, firebelly toad, Bombina microdeladigitora, which is a subspecies of B. maxima and occupies similar geographical regions [56, 91]. This suite of AMPs included nearly 80 peptides, indicating an extreme of diversity that had not previously been reported for a single species of frog and the reason for which was unclear. However, evidence was presented, which suggested that maximin H5 and homologous AAMPs have anti-nociceptive properties and may also serve as neuropeptides [56]. This observation clearly suggested that the diversity of AMPs produced by B. maxima and B. microdeladigitora might enhance the capacity of these organisms for survival by providing peptides able to perform multiple roles in their innate immune response, giving a clear example of the functional promiscuity of AMPs $[10,92]$. As a matter of historical interest, some of the earliest anionic peptides to be isolated from amphibians were bombesins and tachykinins from Pseudophryne güntheri [93], which are families of molecules that serve as hormones and neurotransmitters [94-95]. These signalling molecules have been extensively studied in amphibians [96-97] and it is now generally accepted that they are able to exert antimicrobial activity whilst, conversely, AAMPs produced by these organisms can exhibit immunomodulatory function [5, 98]. It may be that this strategy is common, although many anionic neuropeptides identified within frogs and toads have yet to be tested for antimicrobial potential $[5,99]$.

\subsection{The antibacterial action of maximin $\mathrm{H5}$}

Several studies have shown that maximin H5 exhibits activity against S. aureus [44, 54]. Recent experimental work and molecular dynamic (MD) simulations to involve membranolytic mechanisms [54, 89]. This work showed that the membrane interactive form of the peptide was a hairpin-type $\alpha$-helical conformation whose partitioning into the bilayer was stabilised by a variety of lipid-peptide and intra peptide bonds. The major driver of the membranolytic mechanisms used by maximin H5 appeared to be the formation of a tilted $\alpha$-helix in the peptide's amidated N-terminal segment, $\mathrm{H}_{2} \mathrm{~N}$-I1-S10 (Table 2). This tilted $\alpha$-helical structure induced deep bilayer penetration by this segment at an angle of $\operatorname{circa} 45^{\circ}$ (Fig. 2A). Tilted $\alpha$-helices possess an asymmetric distribution of hydrophobicity along the $\alpha$-helical long axis that induces membrane penetration at a shallow angle, and have been identified in a number of AMPs, and AAMPs, such as A $\beta 42$ and A $\beta 40$ [12, 100]. The net negative charge carried by maximin $\mathrm{H} 5$ resulted from an internal cluster of aspartate residues, which formed a short $\alpha$-helical region that flanked the $\mathrm{N}$-terminal tilted $\alpha$-helical segment of the peptide. These aspartate residues were distal from the membrane surface and appeared to play no direct role in the lipid interactions of maximin H5, rather, serving a primarily structural role [89]. The amidated C-terminal segment, V16-L20- $\mathrm{NH}_{2}$, of maximin $\mathrm{H} 5$ (Table 2) was found to play a key role in its membranolytic activity by forming an intra-peptide hydrogen bonding network with the N-terminal region of the peptide 
that stabilised its tilted $\alpha$-helical structure (Fig. 2A). A number of recent studies have shown that the activity of some AAMPs against $S$. aureus are influenced by $\mathrm{pH}$ [101], such as that of hebraein (net charge -4), which is produced by Amblyomma hebraeum [102] and other ticks [103-104]. This was also found to be the case for maximin H5 when a very recent study showed that low $\mathrm{pH}$ enhanced the membranolytic action of the peptide against $S$. aureus, making maximin $\mathrm{H} 5$ the only major amphibian AAMP reported to possess $\mathrm{pH}$ dependent antibacterial activity [54]. Low $\mathrm{pH}$ appeared to have the general effect of enhancing the levels of amphiphilic $\alpha$-helical structure possessed by maximin H5, thereby maximising its membranolytic ability and facilitating the killing of $S$. aureus via a 'carpet'-type mechanism [54, 89], which is that most commonly used by $\alpha$ helical AMPs $[12,105]$. According to this mechanism, increasing levels of maximin H5 'carpet' membranes of $S$. aureus in a nonspecific manner, thereby inducing progressively greater numbers of lesions and ultimately, membranolysis [54, 89]. It is believed that a number of other amphibian AMPs eradicate bacteria via the 'Carpet' mechanism with a tilted $\alpha$-helical structure incorporated into their lytic action [12, 100]. Examples include aurein 2.3 from Green and Golden Bell frog, Litoria aurea [106]. Comparisons were made between the tilted $\alpha$-helix of maximin H5 [54, 107] and that of the anionic influenza haemagglutinin peptide, HA2 [100, 108], which has a low $\mathrm{pH}$ optimum for the adoption of tilted $\alpha$-helical structure and membranolytic action [109]. These comparisons revealed many compositional and structural similarities between the two molecular architectures and led to the suggestion that low $\mathrm{pH}$ enhanced the activity of maximin H5 against $S$. aureus primarily by maximising its level of $\mathrm{N}$-terminal tilted $\alpha$-helical structure [54]. In combination, these observations indicate that maximin $\mathrm{H} 5$ exerts antibacterial activity via a $\mathrm{pH}$ dependent antimicrobial mechanism that has not yet been reported for AAMPs or, indeed, AMPs in general [101].

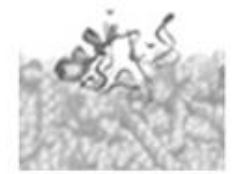

A. Maximin H5 partitioned into $S$. aureus membranes.

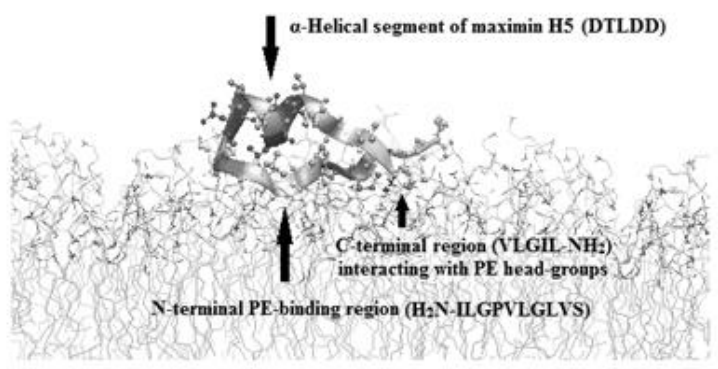

C. The interaction of segments of maximin H5 with PE head-groups.

Figure 2. MD simulations of maximin H5 interacting with bacterial cell membranes. Figure 2 was revised from $[89,110]$ and depicts snapshots of MD simulations of the interaction of maximin H5 with various bacterial membranes. Figure 2A shows the peptide inserted into $S$. aureus membranes utilising a hairpin-type $\alpha$-helical conformation whose partitioning into the bilayer was stabilised by a variety of lipid-peptide and intra peptide bonds and involved the peptide's amidated terminal segments, $\mathrm{H}_{2} \mathrm{~N}-\mathrm{I} 1-\mathrm{S} 10$ and V16-L20- $\mathrm{NH}_{2}$ [89]. Maximum $\mathrm{H} 5$ shows specificity for $S$. aureus and appears to kill the organism via $\mathrm{pH}-$ dependent membranolytic mechanisms that involve the strongly $\alpha$-helical N-terminal region of the peptide [54]. Figure 2A clearly shows this $\mathrm{N}$-terminal segment inserting into the membranes at an angle of circa $45^{\circ}$, which is typical of tilted AMPs [100, 111-112]. These observations strongly support previous studies, which have suggested that the antibacterial activity of the peptide may involve the $\mathrm{pH}$ dependent, adoption of membranolytic-tilted structure [54, 107]. Figure 2B shows MD simulations of maximin $\mathrm{H} 5$ interacting with the surface of $E$. coli membranes, which include circa $80 \%$ phosphatidylethanolamine (PE), and it appears that the high affinity of the peptide for PE renders it immobilised on the surface of these membranes [88]. Figure $2 \mathrm{C}$ shows an enlarged version of Figure $2 \mathrm{~B}$, which indicates that in the presence of PE, maximin $\mathrm{H} 5$ undergoes a conformational change that leads to random coil structure in its amidated $\mathrm{N}$-terminal tilted segment, $\mathrm{H}_{2} \mathrm{~N}-\mathrm{I} 1-\mathrm{S} 10$, and the absence of intra peptide interactions between this segment and the amidated C-terminal segment, V16- $220-\mathrm{NH}_{2}$, of the peptide. This conformational rearrangement promotes membrane binding by maximin $\mathrm{H} 5$ with the major contributions coming from hydrogen bonding between phosphate and ammonium groups within the PE head-group and residues in both terminal regions 
of the peptide. In particular, the N-terminal region of maximin H5 shows high affinity for PE, which was proposed to involve the ability of this segment to mimic structural properties of the PE-binding pocket formed by a number of prokaryotic AMPs. In combination, these various interactions appear to anchor maximin $\mathrm{H} 5$ to the surface of $E$. coli membranes, thereby inhibiting the ability of the peptide to adopt the membrane interactive tilted $\alpha$-helical structure necessary for its antimicrobial activity [88, 110].

\subsection{Bacterial resistance to the action of maximin $\mathrm{H} 5$}

$S$. aureus has evolved a wide repertoire of resistance mechanisms to counter the action of AMPs and other host defence molecules [113-114] including a number that are influenced by $\mathrm{pH}$ [101], as recently shown for the resistance of both $S$. aureus and methicillin-resistant $S$. aureus (MRSA) to analogues of magainin 2 from X. laevis [115]. This possibility was investigated for maximin $\mathrm{H} 5$, and it was found that $S$. aureus had developed protection from the action of the peptide. This protection was $\mathrm{pH}$ dependent and involved lys-PG in the membranes of the organism [54]. It is well established that levels of lys-PG in $S$. aureus membranes are elevated at low $\mathrm{pH}$, which enhances the ability of the lipid to attenuate properties of these membranes and thereby enable the organism to resist AMPs [115]. Consistent with these observations, it was shown that the elevated levels of lys-PG present in $S$. aureus membranes at low $\mathrm{pH}$ reduced the net negative surface charge carried by these membranes and affected characteristics of their structural order, such as lipid packing and membrane fluidity, thereby inducing rigidification. These effects appeared to inhibit the ability of maximin H5 to target and penetrate membranes of $S$. aureus, which was surprising given that the peptide carries a net negative charge [44] and lys-PG mediated mechanisms of resistance appear to have evolved primarily to protect the organism from CAMPs $[19,114]$. To explain this apparent contradiction, it was suggested that the membranolytic form of maximum H5 effectively acted as a CAMP via the amidated residues at its two termini, which are the only positively charged residues possessed by the peptide [54]. Consistent with this suggestion, MD simulations showed that these amidated residues were relatively more accessible to external molecules than the internally located, anionic residues possessed by the peptide (Fig. 2) [88, 90, 110]. These findings appeared to help explain how maximum H5 targeted membranes of $S$. aureus and also why the peptide was able to evade some adaptive mechanisms of resistance possessed by the organism to combat anionic AMPs $[114,116]$. Further investigations into the antimicrobial action of maximin H5 showed that with the exception of $S$. aureus, the peptide had no activity against other Gram-positive bacteria, Gram-negative bacteria, fungi or enveloped viruses [44, 88, 90, 117]. A clear difference between these two groups of microbes was the presence of phosphatidylethanolamine (PE) in the membranes of organisms resistant to the action of maximin $\mathrm{H} 5$ and the absence of this lipid in the membranes of microbes susceptible to its activity [118-120]. Studies on E. coli showed that maximin H5 had no propensity to partition into membranes derived from this organism, or other PE-containing membranes. Also the peptide was predicted by MD simulations to remain bound to the surface of these bilayers via a variety of peptide-lipid interactions and intra-peptide associations (Figs 2B and 2C). The major contributions to this peptide-membrane binding came from hydrogen bonding between phosphate and ammonium groups within the PE head-group and residues in both terminal regions of maximin H5 [88, 110]. Essentially, in relation to the membranolytic form of the peptide (Fig. 2A) [89-90], maximin H5 appeared to undergo a conformational change in the presence of PE that led to random coil structure in its amidated N-terminal segment, $\mathrm{H}_{2} \mathrm{~N}-\mathrm{I} 1-\mathrm{S} 10$ and the absence of intra-peptide interactions between this segment and the amidated C-terminal segment, V16L20- $\mathrm{NH}_{2}$, of the peptide (Table 2) (Figs. 2B and 2C) [88, 110]. The N-terminal PE-binding sequence of the peptide showed significant homology to those of the bacterial AMPs, cinnamycin and duramycin, which suggested that the affinity of maximin H5 for the lipid may involve an ability to mimic structural properties of the PE-binding pocket formed by these prokaryotic peptides [110]. Consistent with this proposal, a CAMP with potent activity against the enveloped virus, human immunedeficiency virus was produced by substituting arginine residues for the three aspartate residues of maximin H5 [117], thereby destabilising the PE binding conformation of the peptide [88, 110]. Taken in combination, these observations suggested that maximin H5 has high affinity for PE that induces immobilisation of the peptide on the surface of membranes, which include the lipid, thereby inhibiting the ability of maximin $\mathrm{H} 5$ to adopt the membrane interactive tilted $\alpha$-helical structure necessary for its antimicrobial activity $[88,110]$.

\subsection{The anticancer activity of maximin $\mathrm{H5}$}

Currently, maximin H5 appears to be the only major focus of research into amphibian AAMPs with anticancer activity. XLAsp-P1 was shown to inhibit the growth of MCF-7 cells, which is a human breast adenocarcinoma cell line, but no further studies on mechanisms underpinning this activity of were conducted [33]. In contrast, several studies have shown that maximin H5 has activity against the T98G glioblastoma cell line and exhibits specificity for these cells over non-cancerous cells [29, 55]. These observations showed that, although PE is present the outer membrane leaflet of cancer cells [121-122], the affinity of the lipid for maximin $\mathrm{H} 5$ did not inhibit the action of the peptide against T98G glioblastoma cells, contrasting with the case of $E$. coli, described above (Fig. 2) [88, 110]. It was proposed that these effects were most likely related to the fact that the lipid 
forms circa $80 \%$ of the E. coli inner membrane [123] but constitutes less than $30 \%$ of the lipid in the outer membrane leaflet of T98G cells [124]. Indeed, on this premise, maximin H5 may show activity against other cancer cells, which generally exhibit lower levels of PE [125-126], as in the case of cells of the breast cancer cell line, MCF-7, which include around 15\% of the lipid in their outer leaflet [127].

Characterisation of the anticancer action of maximin H5 showed that it adopted high levels of $\alpha$-helical structure that facilitated membranolytic action against cancer cell membranes [55]. These studies also showed that this action was promoted by anionic lipid and required the presence of the peptide's terminal amide moieties for optimal anticancer effect, supporting the view that maximin H5 effectively acts as a CAMP [54, 89]. It is well established that CAMPs interact with cancer and microbial membranes through generally similar mechanisms, targeting the negative surface charge carried by both these membrane types [128-129]. To investigate the interaction of maximin H5 with cancer cell membranes at the molecular level, here we present MD simulations of the peptide interacting with a bilayer composed of PC and PS in a 10:1 molar ratio. This lipid composition corresponds to that used to mimic cancer cell membranes in the experimental work of Dennison et al., [55] and consistent with this work, our MD simulations predicted that native maximin H5 would partition into these bilayers primarily through the formation of high levels of $\alpha$-helical architecture (Fig.3A (i)). Similar to the antibacterial form of the native peptide [89] (Fig. 2A), this $\alpha$-helical architecture primarily resides in the segments, $\mathrm{H}_{2} \mathrm{~N}-\mathrm{I} 1-\mathrm{S} 10$ and V16-L20-NH 2 , of maximin $\mathrm{H} 5$ (Fig. 3A (i)). These segments of the peptide were predominantly associated with DMPS molecules in the membrane and facilitated penetration of the hydrophobic core of the bilayer, as indicated by the partial density profile of native maximin H5 (Fig. 3A (ii)). In particular, hydrophobic residues in the terminal segments of this peptide interacted with the acyl chains of DMPS whilst charged and polar residues in these segments associated with moieties in the head-group region of the lipid, such as phosphate groups. The overall lipid interactive conformation of native maximin H5 was stabilised by high levels of hydrogen bonding, which was predominantly between residues within these $\mathrm{N}$-terminal and $\mathrm{C}$-terminal segments and multiple components of the bilayer (Fig. 3A (i)). These observations are generally consistent with experimental work [55] and indicate that native maximin H5 has a strong preference for anionic lipid over zwitterionic lipid, providing a basis for the observed ability of PS to promote the membranolytic and anticancer action of the peptide.

A

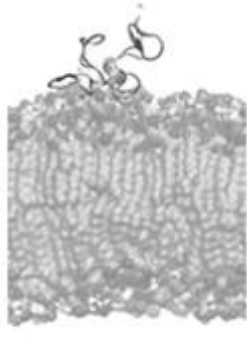

(i)

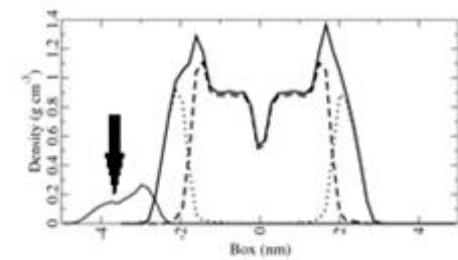

(ii)

B

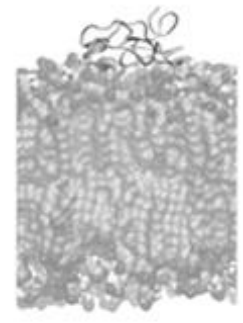

(i)

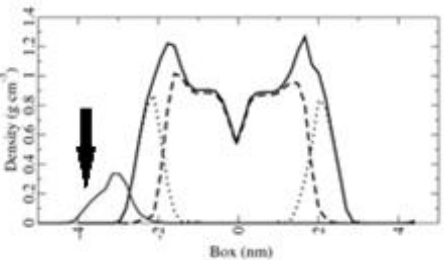

(ii)

Figure 3. MD simulations of maximin H5 interacting with cancer cell membranes. Figures $3 \mathrm{~A}$ (i) and 3B (i) show side elevations of MD simulations for the interaction of maximin H5 and its deaminated isoform, respectively, with bilayers formed from DMPS / DMPC (10:1) and this lipid composition was taken to represent cancer cell membranes as previously described [130-131]. A detailed description of these lipid interactions is provided above but essentially, these simulations predicted that 
both peptides partitioned into these bilayers via an $\mathrm{N}$-terminal region comprising 10 residues and a shorter C-terminal segment. These MD simulations also generated partial density profiles and the graphics in each panel shows partial densities of the components in each peptide / lipid system (Figures 3A (ii) and 3B (ii): overall lipid density (solid black line), lipid head-groups (dotted line), lipid tails groups (dashed line) and peptide (solid line and indicated by arrows). A comparison of the partial density profiles for peptides, predicts that maximin H5 (Figure 3A (ii)) would penetrate the hydrophobic membrane core region of DMPS / DMPC (10:1) membranes more deeply than its deaminated isoform (Figure 3B (ii)). MD simulations were performed as previously described except that lipid bilayers were constructed from lipid mixtures of DMPS / DMPC in a molar ratio of 10:1 [88].

To investigate a requirement for the terminal amide groups in the anticancer activity, of maximin H5, our MD simulations were repeated using a C-terminally deaminated isoform of the peptide. Clearly, the loss of this C-terminal amide might be expected to reduce the membranolytic ability of the peptide through a decreased potential to interact with anionic lipid components of these membranes. However, our MD simulations predicted that deamination also would also lead to a loss of $\alpha$ helical structure in the $\mathrm{C}$-terminal segment of native maximin $\mathrm{H} 5$ and a reduction in the level of hydrogen bonding between this segment and components of the bilayer (Fig.4B (i)). As indicated by the partial density profile of the deaminated peptide, these C-terminal effects appeared to contribute to a decrease in the depth of penetration shown by the peptide into the hydrophobic core of the bilayer (Fig. 3B (ii)) as compared to native maximin H5 (Fig. 3A (ii)). Graphical analysis shows that native maximin $\mathrm{H} 5$ is strongly amphiphilic in an $\alpha$-helical conformation with a clear segregation of hydrophobic and hydrophilic residues (Fig. 4). In combination, these observations suggest that the $\mathrm{C}$-terminal amide of the native peptide helps maintain the levels of amphiphilicity required for the optimal lysis of cancer cell membranes. Indeed, it is well established that the presence of C-terminal amide groups enhances the propensity of AMPs to form $\alpha$-helical structure by making an additional hydrogen bond available for stabilisation of this structure [132-133]. Taken overall, our MD simulations strongly support experimental data suggesting that the C-terminal amide possessed by native maximin H5 plays a key role in optimising the ability of the peptide to kill cancer cells [55] and predict that it facilitates this ability through multiple functions related to the promotion of membrane targeting and interaction.

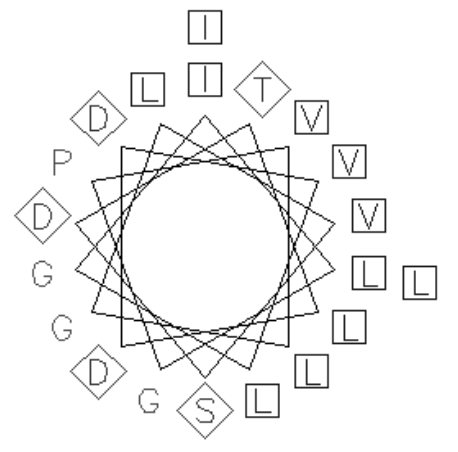

Figure 4. The amphiphilicity of maximin H5. Figure 4 shows $\alpha$-helical maximin H5 displayed as a two-dimensional axial projection. This $\alpha$-helical arrangement is strongly amphiphilic and shows a clear segregation of hydrophilic and hydrophobic amino acid residues. The wide apolar face of the $\alpha$-helix is primarily formed by strongly hydrophobic residues, such as valine, leucine and isoleucine, whilst the narrow polar face is mainly formed from anionic, aspartic acid residues and glycine residues. The possession of a glycine-rich polar face is a feature shared by a number of tilted peptides [112] and it is believed that this segregation of glycine residues promotes a more favourable free energy of membrane insertion because the asymmetric distribution of the bulkier, hydrophobic residues along the other side of the $\alpha$-helical axis is able to drive penetration of the membrane at a shallow angle [134].

\section{CONCLUSIONS}

Here, current research into amphibian AAMPs has been reviewed, which shows that the majority of these peptides have been identified in newts, frogs and toads (Table 2). A number of amphibians show the potential to produce the AAMPs, peptide $\mathrm{B}$ and enkelytin, which are cleaved from larger proteins, although this production has yet to be experimentally demonstrated (Table 3). The diversity of these amphibians taken with the fact that they are resident across wide geographical areas on a 
number of continents would seem to reinforce the view that AAMPs are important components of innate immune systems [2629].

The net charge of the AAMPs reviewed here ranged from -1 to -8 , and these peptides appear to use a variety of mechanisms to target and interact with microbes, such as the ability of maximin $\mathrm{H} 5$ to effectively function as a CAMP. This would appear to be the first report of such behaviour for an amphibian peptide, although it has been described for AAMPs from plants [26, 135]. In contrast, some AAMPs reviewed here are composed entirely of negatively charged residues, such as PYL, and appear to interact with microbial membranes by co-opting cationic metal ions to form salt bridges. However, other amphibian AAMPs entirely composed of anionic residues, such as XLAsp-P1, interact with membranes via mechanisms that are independent of cationic metal ions, and in these cases, the underpinning mechanisms are unclear. It seems likely that the membrane interactions of these peptides may involve association with positively charged components of the microbial membrane such as the ammonium moiety of PE and cationic lipids such as Lys-PG.

A number of the peptides reviewed here, including: he-1, thaulin-4, pleurain-C2, brevinin-1-AJ3, jingdongin-2 and PD-3-7, were either not tested for antimicrobial activity or found to be ineffective against the microbes assayed (Table 4). However, it seems possible that, in some cases, this apparent lack of antimicrobial action might simply represent the small ranges of bacteria and fungi that were generally used to assay this activity. For example, the amyloid-forming peptide, PD-3-7, was reported as possessing no antibacterial activity based on assays against only two organisms [52]. However, AMPs with amyloid-mediated antimicrobial mechanisms are increasingly being reported, and further studies on the ability of PD-3-7 to act in this capacity would seem to be merited [12,60]. Interestingly, very recent studies have shown that human $\alpha$-defensin 6 also lacks direct antibacterial activity but binds to surface proteins of these organisms, which triggers ordered self-assembly to form fibrils and amyloid nanonets that surround and entangle target bacteria [136]. Several of the AAMPs reviewed here were multifunctional with defensin-TK, CFBD-1, XLAsp-P2 and pleurain-C1 showing antifungal activity, whilst XLAsp-P1 and maximin H5 exhibited anticancer action. The remaining AAMPs were either ineffective against the fungi or cancer cells tested or were not assayed for activity against these target cells (Table 4). Several peptides showed other biological roles, such as insecticidal activity in the case of PD-3-7 and serving as a propeptide in the case of PYL (Table 4). Indeed, in the latter case, it appears that antimicrobial function is a secondary role for the peptide [31]: similar observations have been made for a number of non-amphibian AAMPs [26]. Maximin H5 appeared to be the only peptide reviewed here with neuropeptide function (Table 4), although it has been predicted that a number of homologous AAMPs may share this property [56]. It would seem that this localisation of antimicrobial and neuropeptide capability within single peptides might be an important strategy for the promotion of a rapid unified neuroimmune response by the amphibian host. This strategy clearly differs fundamentally from that mediated by the processing of PENK where antimicrobial and neuropeptide functions reside separately in AAMPs and opioid peptides (Figure 1) [85-86]. Currently, the presence of this opioid hormone in B. maxima does not appear to have been investigated, although it has been identified in the brain of the closely related Oriental Fire-bellied Toad, Bombina orientalis (Table 3)[49]. In combination, these observations suggest that the brains of amphibians may have a number of strategies for providing a coordinated neuroimmune response to threats such as microbial challenge, stress, or other stimuli.

This review has shown that some progress has been made in elucidating the mechanisms underpinning the biological activities of amphibian AAMPs. For example, XLAsp-P1 appeared to kill bacteria using a toroidal pore type mechanism, and the action of XLAsp-P2 shows hallmark characteristics of the SHM model of membrane interaction. This latter peptide also showed the ability to potentiate the action of conventional antibiotics against MDR pathogens, and the potential advantages of this form of combination therapy are increasingly being recognised and are viewed as a major, potential strategy for combating microbial pathogens with MDR [137-138]. For example, combination treatment can potentially reduce the required dosage of individual drugs, thereby diminishing side effects, as well as, not only eliminating resistant strains, but also delaying the emergence of drug resistance [139-140]. Indeed, it has been observed that combination therapy to potentiate failing antibiotics could be an interim solution to the global problem of MDR pathogens until sufficient numbers of novel antimicrobial molecules and strategies become available [141].

Several AAMPs reviewed here, namely PD-3-7 and maximin H5, exhibited pH-dependent mechanisms of biological activity, which is relatively rare amongst amphibian AMPs [101]. In the case of PD-3-7, this activity appeared to involve epimerisation and $\mathrm{pH}$-dependent amyloid formation, which led to the proposal that studies on amyloidogenesis by these epimers could help understand the pathogenesis of disease-related amyloid, such as AD [52-53]. It is well established that Denantiomers of residues are present in the $A \beta$ peptides, and elevated levels of these residues have been described in amyloid plaques and the brain tissue of AD patients [142]. Based on the $\mathrm{pH}$-dependent reversibility of amyloid formation by PD-3-7, it has also been proposed that studies on the peptide could aid the development of amyloid-based nanomaterials [52-53]. The ability of amyloid to reversibly self-assemble has been employed in the design of long-acting drugs where the sustained and controlled release of biologically active peptides occurs from the termini of fibrils [143]. Currently, the number of known amyloidogenic AAMPs is increasing [60], such as the recently reported Cn-AMP2 from the Coconut, Cocos nucifera [144]. In addition, functional amyloid nanostructures are being developed for use in a growing number of diverse areas, such as tissue repair / engineering, which is of high technological and medical importance [143, 145]. 
In the case of maximin $\mathrm{H} 5$, there is strong evidence to suggest that the peptide kills $S$. aureus using a pH dependent membranolytic mode of action that encompasses tilted peptide formation. Interestingly, it can be seen from Figure 4 that the hydrophilic face of the tilted $\alpha$-helix formed by maximin $\mathrm{H} 5$ is rich in glycine residues, a feature shared by a number of tilted peptides [112]. It is believed that this segregation of glycine residues promotes a more favourable free energy of membrane insertion because the asymmetric distribution of the bulkier, hydrophobic residues along the other side of the $\alpha$-helical axis is able to drive penetration of the membrane at a shallow angle [134]. A number of amphibian AMPs with tilted structure incorporated into their lytic action have been previously reported $[100,106,146]$ and together, these results have the potential to aid the design of novel AMPs with $\mathrm{pH}$ dependent biological activity, which is currently, a major area of research [101]. Recent work has described such peptides for action against bacteria, fungi, biofilms and cancer cells, as well as for biotechnical applications involving the delivery of drugs and genes [101]. S. aureus has developed protection from the action of maximin $\mathrm{H} 5$ by modulating its membrane properties but the peptide has successfully overcome this defensive shield. It is notable that the membranolytic mode of action used by maximin $\mathrm{H} 5$ is enhanced by the low $\mathrm{pH}$ conditions that favour the growth of $S$. aureus [54]. This observation tempts the speculation that the secretion of the peptide by B. maxima [44], may have developed specifically to combat the organism, particularly in view of the fact that $S$. aureus appears to be the sole microbial target of the peptide [44, 117]. These observations would seem to provide a clear illustration of the co-evolutionary processes of mutual inhibition, evasion and adaptation strategies that characterise host-pathogen interactions [23], a scenario often referred to as the microbial 'arms race' [17-18, 147]. Moreover, given the low levels of haemolysis shown by maximin H5, it would seem that the peptide is worthy of further investigation as a potential template for development as an anti-staphylococcal agent [44, 54, 89]. In contrast to $S$. aureus, E. coli exhibits resistance to the action of maximin H5, and this resistance appears to be based on the ability of the peptide to bind PE with high affinity. It has previously been suggested that some plant AAMPs and other AMPs with a similar affinity for PE may serve as lead compounds for tumour imaging [110, 148-149]. Interestingly, what would appear to be the first $\mathrm{pH}$-dependent anionic, antimicrobial protein identified in amphibians was recently reported when phylogenetic analyses predicted that homologues of human psoriasin would be expressed in a number of amphibians [150]. It is well-established that human psoriasin exhibits $\mathrm{Zn}^{2+}$-dependent and $\mathrm{pH}$-dependent activity in the antimicrobial defence of the skin [101], and a homologue of the protein, designated RtS100A7 (net charge -5) was detected in the skin secretions of the European Common Frog, Rana temporaria [150]. In contrast to human psoriasin, RtS100A7 was ineffective against $E$. coli at neutral $\mathrm{pH}$, which appeared to result from an inability to form $\mathrm{Zn}^{2+}$ binding sites, a property that underpins activity of human psoriasin against the organism. However, similarly to human psoriasin, RtS100A7 showed membranolytic activity towards $B$. megaterium and $B$. subtilis at low $\mathrm{pH}$, although this activity was weaker than that of human psoriasin. Based on these observations, it was proposed that RtS100A7 might function in the innate immunity of $R$. temporaria by synergising the activity of other AMPs in the skin of the amphibian [150].

Maximin H5 and XLAsp-P1 were both found to exert anticancer activity, which would make these peptides the first amphibian AAMPs reported to possess this ability. This reinforces the view that these creatures are becoming an increasingly important source of novel agents to combat cancer, a leading, global cause of death [151-152]. Indeed, AAMPs in general, are viewed as attractive propositions to stem the diminishing flow of effective, conventional anticancer compounds [99, 153-156], although currently, the majority of these peptides are primarily derived from plants [28-29]. The ability of maximin $\mathrm{H} 5$ and XLAsp-P1 to exert anticancer activity distinguishes these peptides from many AMPs, which do not exhibit this ability and the reason for this varying functionality is currently unclear [128-129, 156-157]. It is an open debate as to whether the possession of anticancer activity by AMPs has developed to give the host organism a survival advantage or it is just a matter of serendipity. However, it is interesting to note that there is a strong link between many microbial infections and cancers in humans [158-159], such as those due to human papillomaviruses where the insertion of viral DNA into human DNA can damage chromosomes and genes, resulting in cancers of the cervix, neck and head [160-163]. In this light, it can be envisaged that agents with the capacity to simultaneously attack cancers and their associated viral and bacterial infections would be therapeutically beneficial. Indeed, it would seem that the potential of maximin $\mathrm{H} 5$ to serve in this capacity could be enhanced by its plasticity as a template in the production of derivatives with multiple mechanisms of activity and differing specificities [54]. For example, maximin H5 possesses no antiviral properties itself [117], but nanomaterials based on the peptide were found to be active against phage $\lambda$ [164-165], showing the potential to treat disease associated biofilms rendered recalcitrant to conventional antibiotics by phage infected bacteria [166].

In summary, this review has shown that AAMPs are produced by creatures across Amphibia and that these peptides are primarily active against a variety of microbes and cancer cells. There has been some progress towards characterising these AAMPs and several have the potential for medical and biotechnological applications. Currently, the best characterised of these peptides is maximum H5, which primarily appears to provide a lead compound for the development of novel antibacterial, antiviral and anticancer compounds. However, in general, amphibian AAMPs appear to receive relatively little research attention and would seem to represent an untapped potential source of novel biologically active agents that merit far greater investigation.

\section{CONFLICT OF INTEREST}


The authors declare no conflict of interest

\section{AUTHOR CONTRIBUTIONS}

SRD, FH, MM and DAP wrote the paper. MM performed the molecular dynamics.

\section{REFERENCES}

[1] Crump, M., Eye of Newt and Toe of Frog, Adder's Fork and Lizard's Leg: The Lore and Mythology of Amphibians and Reptiles. University of Chicago Press: 2015.

[2] Liu, M. C.; Feng, L.; Hu, L.; Liu, X.; Guo, D., Advancement in research of anti-cancer effects of toad venom (ChanSu) and perspectives. Modern Research on Chinese Materia Medica 2015, 1 (2), 12-23.

[3] Kamboj, A.; Rathour, A.; Kaur, M., Bufadienolides and their medicinal utility: A review. Int J Pharm Pharm Sci 2013, 5 (4), 20-27.

[4] Clarke, B. T., The natural history of amphibian skin secretions, their normal functioning and potential medical applications. Biol Rev Camb Philos Soc 1997, 72 (3), 365-79.

[5] Xu, X. Q.; Lai, R., The Chemistry and Biological Activities of Peptides from Amphibian Skin Secretions. Chem. Rev 2015, 115 (4), 1760-1846.

[6] Cardoso, M. H.; Cobacho, N. B.; Cherobim, M. D.; Pinto, M. F. C.; Santos, C. E. A., Insights into the antimicrobial activities of unusual antimicrobial peptide families from amphibian skin. J. Clin. Toxicol. 2014, 4, 1-10.

[7] Conlon, J. M.; Mechkarska, M.; Lukic, M. L.; Flatt, P. R., Potential therapeutic applications of multifunctional hostdefense peptides from frog skin as anti-cancer, anti-viral, immunomodulatory, and anti-diabetic agents. Peptides 2014, 57, 6777.

[8] Kumar, V. T. V.; Holthausen, D.; Jacob, J.; George, S., Host Defense Peptides from Asian Frogs as Potential Clinical Therapies. Antibiotics-Basel 2015, 4 (2), 136-159.

[9] Zasloff, M., Magainins, a class of antimicrobial peptides from xenopus skin - isolation characterisation of 2 active forms, and partial cDNA sequence of a precursor. Proc. Natl. Acad. Sci. U.S.A 1987, 84 (15), 5449-5453.

[10] Phoenix, D. A.; Dennison, S. R.; Harris, F., Antimicrobial Peptides: Their History, Evolution, and Functional Promiscuity. In Antimicrobial Peptides, Wiley-VCH Verlag GmbH \& Co. KGaA: 2013; pp 1-37.

[11] Dennison, S. R.; Harris, F.; Phoenix, D. A., Magainins - A Model for Development of Eukaryotic Antimicrobial Peptides (AMPs). In Novel Antimicrobial Agents and Strategies, Wiley-VCH Verlag GmbH \& Co. KGaA: 2014 ; pp 47-70.

[12] Phoenix, D. A.; Dennison, S. R.; Harris, F., Models for the Membrane Interactions of Antimicrobial Peptides. In Antimicrobial Peptides, Wiley-VCH Verlag GmbH \& Co. KGaA: 2013; pp 145-180.

[13] Maria-Neto, S.; de Almeida, K. C.; Macedo, M. L. R.; Franco, O. L., Understanding bacterial resistance to antimicrobial peptides: From the surface to deep inside. Biochimica et Biophysica Acta (BBA) - Biomembranes 2015, 1848 (11, Part B), 3078-3088.

[14] Steinbuch, K. B.; Fridman, M., Mechanisms of resistance to membrane-disrupting antibiotics in Gram-positive and Gram-negative bacteria. MedChemComm 2016, 7 (1), 86-102.

[15] Dutta, P.; Das, S., Mammalian Antimicrobial Peptides: Promising Therapeutic Targets Against Infection and Chronic Inflammation. Curr. Top. Med. Chem. 2016, 16 (1), 99-129.

[16] da Costa, J. P.; Cova, M.; Ferreira, R.; Vitorino, R., Antimicrobial peptides: an alternative for innovative medicines? Appl Microbiol Biotechnol 2015, 99 (5), 2023-2040.

[17] World Health Organisation. Global action plan on antimicrobial drug resistance; Geneva, Switzerland, 2015.

[18] O'Neill, J. Tackling drug-resistant infections globally: final report and recommendations.; 2016 ; pp 1-84.

[19] Andersson, D. I.; Hughes, D.; Kubicek-Sutherland, J. Z., Mechanisms and consequences of bacterial resistance to antimicrobial peptides. Drug Resist Updat 2016, 26, 43-57.

[20] Mishra, B.; Reiling, S.; Zarena, D.; Wang, G., Host defense antimicrobial peptides as antibiotics: design and application strategies. Curr Opin Chem Biol 2017, 38, 87-96.

[21] Zasloff, M., Antimicrobial Peptides: Do They Have a Future as Therapeutics? Birkhauser Verlag Ag, Viadukstrasse 40-44, Po Box 133, Ch-4010 Basel, Switzerland: 2016; p 147-154.

[22] Wang, G. S.; Li, X.; Wang, Z., APD3: the antimicrobial peptide database as a tool for research and education. Nucleic Acids Res 2016, 44 (D1), D1087-D1093.

[23] Peschel, A.; Sahl, H.-G., The co-evolution of host cationic antimicrobial peptides and microbial resistance. Nat Rev Micro 2006, 4 (7), 529-536.

[24] Phoenix, D. A.; Dennison, S. R.; Harris, F., Cationic Antimicrobial Peptides. In Antimicrobial Peptides, Wiley-VCH Verlag GmbH \& Co. KGaA: 2013; pp 39-81. 
[25] Teixeira, V.; Feio, M. J.; Bastos, M., Role of lipids in the interaction of antimicrobial peptides with membranes. Prog Lipid Res 2012, 51 (2), 149-177.

[26] Harris, F.; Dennison, S. R.; Phoenix, D. A., Anionic Antimicrobial Peptides from Eukaryotic Organisms. Curr Protein Pept Sci 2009, 10 (6), 585-606.

[27] Harris, F.; Dennison, S. R.; Phoenix, D. A., Anionic Antimicrobial Peptides from Eukaryotic Organisms and their Mechanisms of Action. Curr Chem Biol 2011, 5 (2), 142-153.

[28] Prabhu, S.; Dennison, S. R.; Lea, B.; Snape, T. J.; Nicholl, I. D.; Radecka, I.; Harris, F., Anionic Antimicrobial and Anticancer Peptides from Plants. Crit Rev Plant Sci. 2013, 32 (5), 303-320.

[29] Harris, F.; Prabhu, S.; Dennison, S. R.; Snape, T. J.; Lea, R.; Mura, M.; Phoenix, D. A., Anionic Host Defence Peptides from the Plant Kingdom: Their Anticancer Activity and Mechanisms of Action. Protein peptide lett 2016, 23 (8), 67687.

[30] Laverty, G.; Gorman, S. P.; Gilmore, B. F., The Potential of Antimicrobial Peptides as Biocides. Int. J. Mol. Sci. 2011, $12(10), 6566-6596$.

[31] Brogden, K. A.; Ackermann, M.; Huttner, K. M., Small, anionic, and charge-neutralizing propeptide fragments of zymogens are antimicrobial. Antimicrob Agents Chemother 1997, 41 (7), 1615-1617.

[32] Zhang, Y.; Liu, S.; Li, S.; Cheng, Y.; Nie, L.; Wang, G.; Lv, C.; Wei, W.; Cheng, C.; Hou, F.; Hao, L., Novel short antimicrobial peptide isolated from Xenopus laevis skin. Journal of peptide science : an official publication of the European Peptide Society 2017, 23 (5), 403-409.

[33] Li, S.; Hao, L.; Bao, W.; Zhang, P.; Su, D.; Cheng, Y.; Nie, L.; Wang, G.; Hou, F.; Yang, Y., A novel short anionic antibacterial peptide isolated from the skin of Xenopus laevis with broad antibacterial activity and inhibitory activity against breast cancer cell. Arch Microbiol 2016.

[34] Rödder, D.; Ihlow, F.; Courant, J.; Secondi, J.; Herrel, A.; Rebelo, R.; Measey, G. J.; Lillo, F.; De Villiers, F. A.; De Busschere, C.; Backeljau, T., Global realized niche divergence in the African clawed frog Xenopus laevis. Ecol. Evol 2017, 7 (11), 4044-4058.

[35] Oscar, V.-H.; Lorena, H.-O.; Maria del Carmen, R.; Fernando, Z.-Z.; Ruben, C.-F.; Victoria, P.; Cesar, V. F. B., Novel Antimicrobial Peptides Isolated from Skin Secretions of the Mexican Frog Hyla eximia. Protein Peptide Lett 2009, 16 (11), 1371-1378.

[36] Marani, M. M.; Perez, L. O.; de Araujo, A. R.; Plácido, A.; Sousa, C. F.; Quelemes, P. V.; Oliveira, M.; Gomes-Alves, A. G.; Pueta, M.; Gameiro, P.; Tomás, A. M.; Delerue-Matos, C.; Eaton, P.; Camperi, S. A.; Basso, N. G.; de Souza de Almeida Leite, J. R., Thaulin-1: The first antimicrobial peptide isolated from the skin of a Patagonian frog Pleurodema thaul (Anura: Leptodactylidae: Leiuperinae) with activity against Escherichia coli. Gene 2017, 605, 70-80.

[37] Costa, T. O. G.; Almeida, R. A.; Melo, J. T.; Koolen, H. H. F.; Silva, F. M. A. d.; Leite, J. R. S. A.; Prates, M. V.; Bloch Jr., C.; Pinto, A. C., Isolation and amino acid sequencing by MALDI-TOF-MS/MS of a novel antimicrobial anionic peptide from the skin secretion of Osteocephalus taurinus (Anura, Hylidae). J. Braz. Chem. Soc 2012, 23, 2133-2136.

[38] Yang, H.; Wang, X.; Liu, X.; Wu, J.; Liu, C.; Gong, W.; Zhao, Z.; Hong, J.; Lin, D.; Wang, Y.; Lai, R., Antioxidant Peptidomics Reveals Novel Skin Antioxidant System. Mol. Cell. Proteomics 2009, 8 (3), 571-583.

[39] He, X.; Yang, S.; Wei, L.; Liu, R.; Lai, R.; Rong, M., Antimicrobial peptide diversity in the skin of the torrent frog, Amolops jingdongensis. Amino Acids 2012, 44 (2), 481-487.

[40] Wei, L.; Che, H.; Han, Y.; Lv, J.; Mu, L.; Lv, L.; Wu, J.; Yang, H., The first anionic defensin from amphibians. Amino Acids 2015, 47 (7), 1301-8.

[41] Shen, W.; Chen, Y.; Yao, H.; Du, C.; Luan, N.; Yan, X., A novel defensin-like antimicrobial peptide from the skin secretions of the tree frog, Theloderma kwangsiensis. Gene 2016, 576 (1, Part 1), 136-140.

[42] Meng, P.; Yang, S. L.; Shen, C. B.; Jiang, K.; Rong, M. Q.; Lai, R., The First Salamander Defensin Antimicrobial Peptide. PLoS One 2013, 8 (12).

[43] Wechselberger, C., Cloning of cDNAs encoding new peptides of the dermaseptin-family. Biochim Biophys Acta 1998, $1388(1), 279-83$.

[44] Lai, R.; Liu, H.; Hui Lee, W.; Zhang, Y., An anionic antimicrobial peptide from toad Bombina maxima. Biochem. Biophys. Res. Commun. 2002, 295 (4), 796-799.

[45] Roberts, E.; Shoureshi, P.; Kozak, K.; Szynskie, L.; Baron, A.; Lecaude, S.; Dores, R. M., Tracking the evolution of the proenkephalin gene in tetrapods. Gen. Comp. Endocrinol 2007, 153 (1-3), 189-197.

[46] Walthers, E. A.; Moore, F. L., Cloning proenkephalin from the brain of a urodele amphibian (Taricha granulosa) using a DOR-specific primer in a 3 ' RACE reaction. Gen. Comp. Endocrinol 2005, 142 (3), 364-370.

[47] Wong, M.; Rius, R. A.; Loh, Y. P., Characterisation of Xenopus Laevis proenkephalin gene. Mol. Brain Res 1991, 11 (3-4), 197-205.

[48] Hellsten, U.; Harland, R. M.; Gilchrist, M. J.; Hendrix, D.; Jurka, J.; Kapitonov, V.; Ovcharenko, I.; Putnam, N. H.; Shu, S. Q.; Taher, L.; Blitz, I. L.; Blumberg, B.; Dichmann, D. S.; Dubchak, I.; Amaya, E.; Detter, J. C.; Fletcher, R.; Gerhard, D. S.; Goodstein, D.; Graves, T.; Grigoriev, I. V.; Grimwood, J.; Kawashima, T.; Lindquist, E.; Lucas, S. M.; Mead, P. E.; Mitros, T.; Ogino, H.; Ohta, Y.; Poliakov, A. V.; Pollet, N.; Robert, J.; Salamov, A.; Sater, A. K.; Schmutz, J.; Terry, A.; Vize, 
P. D.; Warren, W. C.; Wells, D.; Wills, A.; Wilson, R. K.; Zimmerman, L. B.; Zorn, A. M.; Grainger, R.; Grammer, T.; Khokha, M. K.; Richardson, P. M.; Rokhsar, D. S., The Genome of the Western Clawed Frog Xenopus tropicalis. Science 2010, 328 (5978), 633-636.

[49] Dores, R. M.; Costantino, D.; Walnutt, J.; Danielson, P. B.; Lecaude, S., Analyzing the radiation of the proenkephalin gene in tetrapods: cloning of a Bombina orientalis proenkephalin cDNA. Peptides 2001, 22 (12), 2021-2025.

[50] Lecaude, S.; Alrubaian, J.; Sollars, C.; Propper, C.; Danielson, P.; Dores, R. M., Organization of proenkephalin in amphibians: cloning of a proenkephalin cDNA from the brain of the anuran amphibian, Spea multiplicatus 5 . Peptides 2000, 21 (3), 339-344.

[51] Zhou, Y.; Peng, Y. A. N., Synergistic effect of clinically used antibiotics and peptide antibiotics against Gram-positive and Gram-negative bacteria. Exp Ther Med 2013, 6 (4), 1000-1004.

[52] Goessler-Schoefberger, R.; Hesser, G.; Muik, M.; Wechselberger, C.; Jilek, A., An orphan dermaseptin from frog skin reversibly assembles to amyloid-like aggregates in a pH-dependent fashion. Febs Journal 2009, 276 (20), $5849-5859$.

[53] Gossler-Schofberger, R.; Hesser, G.; Reif, M. M.; Friedmann, J.; Duscher, B.; Toca-Herrera, J. L.; Oostenbrink, C.; Jilek, A., A stereochemical switch in the aDrs model system, a candidate for a functional amyloid. Arch. Biochem. Biophys. 2012, 522 (2), 100-106.

[54] Dennison, S.; Morton, L.; Harris, F.; Phoenix, D. A., Low $\mathrm{pH}$ enhances the action of maximin H5 against Staphylococcus aureus and helps mediate lysylated phosphatidylglycerol induced resistance. Biochemistry 2016,55(27), 37353751.

[55] Dennison, S. R.; Harris, F.; Phoenix, D. A., Maximin H5 is an anticancer peptide. Biochimie 2017, In press.

[56] Liu, R.; Liu, H.; Ma, Y.; Wu, J.; Yang, H.; Ye, H.; Lai, R., There are Abundant Antimicrobial Peptides in Brains of Two Kinds of Bombina Toads. Journal of Proteome Research 2011, 10 (4), 1806-1815.

[57] Meneses, E. P.; Villa-Hernández, O.; Hernández-Orihuela, L.; Castro-Franco, R.; Pando, V.; Aguilar, M. B.; Batista, C. V. F., Peptidomic analysis of the skin secretions of the frog Pachymedusa dacnicolor. Amino Acids 2011, 40 (1), $113-122$.

[58] Nicolas, P.; El Amri, C., The dermaseptin superfamily: A gene-based combinatorial library of antimicrobial peptides. Biochim. Biophys. Acta - Biomembranes 2009, 1788 (8), 1537-1550.

[59] Wang, M.; Audas, T. E.; Lee, S., Disentangling a Bad Reputation: Changing Perceptions of Amyloids. Trends Cell Biol 2017, 27 (7), 465-467.

[60] Harris, F.; Dennison, S. R.; Phoenix, D. A., Aberrant action of amyloidogenic host defense peptides: a new paradigm to investigate neurodegenerative disorders? Faseb J 2012, 26 (5), 1776-81.

[61] Zhang, M.; Zhao, J.; Zheng, J., Molecular understanding of a potential functional link between antimicrobial and amyloid peptides. Soft matter 2014, 10 (38), 7425-51.

[62] Kumar, D. K. V.; Choi, S. H.; Washicosky, K. J.; Eimer, W. A.; Tucker, S.; Ghofrani, J.; Lefkowitz, A.; McColl, G.; Goldstein, L. E.; Tanzi, R. E.; Moir, R. D., Amyloid- $\beta$ peptide protects against microbial infection in mouse and worm models of Alzheimer's disease. Sci. Transl. Med 2016, 8 (340), 340ra72-340ra72.

[63] Soscia, S. J.; Kirby, J. E.; Washicosky, K. J.; Tucker, S. M.; Ingelsson, M.; Hyman, B.; Burton, M. A.; Goldstein, L. E.; Duong, S.; Tanzi, R. E.; Moir, R. D., The Alzheimer's disease-associated amyloid beta-protein is an antimicrobial peptide. PLoS One 2010, 5 (3), e9505.

[64] Korshavn, K. J.; Satriano, C.; Lin, Y.; Zhang, R.; Dulchavsky, M.; Bhunia, A.; Ivanova, M. I.; Lee, Y.-H.; La Rosa, C.; Lim, M. H.; Ramamoorthy, A., Reduced Lipid Bilayer Thickness Regulates the Aggregation and Cytotoxicity of AmyloidB. J. Biol. Chem. 2017. 292, 4638-4650.

[65] Evangelisti, E.; Cascella, R.; Becatti, M.; Marrazza, G.; Dobson, C. M.; Chiti, F.; Stefani, M.; Cecchi, C., Binding affinity of amyloid oligomers to cellular membranes is a generic indicator of cellular dysfunction in protein misfolding diseases. Sci Rep 2016, 6, 32721.

[66] Jilek, A.; Mollay, C.; Lohner, K.; Kreil, G., Substrate specificity of a peptidyl-aminoacyl-L/D-isomerase from frog skin. Amino Acids 2012, 42 (5), 1757-1764.

[67] de Magalhaes, M. T.; Barbosa, E. A.; Prates, M. V.; Verly, R. M.; Munhoz, V. H.; de Araujo, I. E.; Bloch, C., Jr., Conformational and functional effects induced by D- and L-amino acid epimerization on a single gene encoded peptide from the skin secretion of Hypsiboas punctatus. PLoS One 2013, 8 (4), e59255.

[68] Kourie, J. I.; Culverson, A. L.; Farrelly, P. V.; Henry, C. L.; Laohachai, K. N., Heterogeneous amyloid-formed ion channels as a common cytotoxic mechanism: implications for therapeutic strategies against amyloidosis. Cell Biochem Biophys 2002, 36 (2-3), 191-207.

[69] Whittington, C. M.; Koh, J. M. S.; Warren, W. C.; Papenfuss, A. T.; Torres, A. M.; Kuchel, P. W.; Belov, K., Understanding and utilising mammalian venom via a platypus venom transcriptome. J Proteomics 2009, 72 (2), $155-164$.

[70] Luca, V.; Barra, D.; Mangoni, M. L., Bombinins. In Handbook of Biologically Active Peptides (Second Edition), Kastin, A. J., Ed. Academic Press: Boston, 2013; pp 331-337. 
[71] Coccia, C.; Rinaldi, A. C.; Luca, V.; Barra, D.; Bozzi, A.; Di Giulio, A.; Veerman, E. C. I.; Mangoni, M. L., Membrane interaction and antibacterial properties of two mildly cationic peptide diastereomers, bombinins $\mathrm{H} 2$ and $\mathrm{H} 4$, isolated from Bombina skin. Eur Biophys J 2011, 40 (4), 577-588.

[72] Bergman, P.; Roan, N. R.; Romling, U.; Bevins, C. L.; Munch, J., Amyloid formation: functional friend or fearful foe? J. Intern. Med. 2016, 280 (2), 139-152.

[73] Maji, S. K.; Perrin, M. H.; Sawaya, M. R.; Jessberger, S.; Vadodaria, K.; Rissman, R. A.; Singru, P. S.; Nilsson, K. P. R.; Simon, R.; Schubert, D.; Eisenberg, D.; Rivier, J.; Sawchenko, P.; Vale, W.; Riek, R., Functional Amyloids as Natural Storage of Peptide Hormones in Pituitary Secretory Granules. Science (New York, N.Y.) 2009, 325 (5938), $328-332$.

[74] Kozić, M.; Vukičević, D.; Simunić, J.; Rončević, T.; Antcheva, N.; Tossi, A.; Juretić, D., Predicting the Minimal Inhibitory Concentration for Antimicrobial Peptides with Rana-Box Domain. J. Chem. Inf. Model 2015, 55 (10), $2275-2287$.

[75] Koyama, T.; Iwamuro, S., Molecular Cloning of a cDNA Encoding Atypical Antimicrobial and Cytotoxic Brevinin1Ja from the Skin of the Japanese Brown Frog, Rana japonica. Zool. Sci 2008, 25 (5), 487-491.

[76] Conlon, J. M.; Sonnevend, A.; Jouenne, T.; Coquet, L.; Cosquer, D.; Vaudry, H.; Iwamuro, S., A family of acyclic brevinin-1 peptides from the skin of the Ryukyu brown frog Rana okinavana. Peptides 2005, 26 (2), $185-190$.

[77] Conlon, J. M.; Abraham, B.; Sonnevend, A.; Jouenne, T.; Cosette, P.; Leprince, J.; Vaudry, H.; Bevier, C. R., Purification and characterization of antimicrobial peptides from the skin secretions of the carpenter frog Rana virgatipes (Ranidae, Aquarana). Regul. Pept. 2005, 131 (1-3), 38-45.

[78] Song, R.; Wei, R. B.; Luo, H. Y.; Wang, D. F., Isolation and characterization of an antibacterial peptide fraction from the pepsin hydrolysate of half-fin anchovy (Setipinna taty). Molecules 2012, 17 (3), 2980-91.

[79] Mandal, S. M.; Dey, S.; Mandal, M.; Sarkar, S.; Maria-Neto, S.; Franco, O. L., Identification and structural insights of three novel antimicrobial peptides isolated from green coconut water. Peptides 2009, 30 (4), 633-637.

[80] Lee, J.; Lee, D.; Choi, H.; Kim, H. H.; Kim, H.; Hwang, J. S.; Lee, D. G.; Kim, J. I., Synthesis and antimicrobial activity of cysteine-free coprisin nonapeptides. Biochem. Biophys. Res. Commun. 2014, 443 (2), $483-488$.

[81] Guo, C.; Hu, Y.; Li, J.; Liu, Y.; Li, S.; Yan, K.; Wang, X.; Liu, J.; Wang, H., Identification of multiple peptides with antioxidant and antimicrobial activities from skin and its secretions of Hylarana taipehensis, Amolops lifanensis, and Amolops granulosus. Biochimie 2014, 105, 192-201.

[82] Wang, X.; Ren, S.; Guo, C.; Zhang, W.; Zhang, X.; Zhang, B.; Li, S.; Ren, J.; Hu, Y.; Wang, H., Identification and functional analyses of novel antioxidant peptides and antimicrobial peptides from skin secretions of four East Asian frog species. Acta Biochim. Biophys. Sin 2017, 49 (6), 550-559.

[83] Yang, X.; Wang, Y.; Zhang, Y.; Lee, W.-H.; Zhang, Y., Rich diversity and potency of skin antioxidant peptides revealed a novel molecular basis for high-altitude adaptation of amphibians. Scientific reports 2016, $6,19866$.

[84] Frost, D., R., Amphibian Species of the World. American Museum of Natural History: 2016.

[85] Salzet, M.; Tasiemski, A., Involvement of pro-enkephalin-derived peptides in immunity. Dev Comp Immunol 2001, 25 (3), 177-185.

[86] Phoenix, D. A.; Dennison, S. R.; Harris, F., Anionic Antimicrobial Peptides. In Antimicrobial Peptides, Wiley-VCH Verlag GmbH \& Co. KGaA: 2013; pp 83-113.

[87] Liu, R.; Liu, H. A.; Ma, Y. F.; Wu, J.; Yang, H. L.; Ye, H. H.; Lai, R., There are Abundant Antimicrobial Peptides in Brains of Two Kinds of Bombina Toads. J. Proteome Res. 2011, 10 (4), 1806-1815.

[88] Dennison, S. R.; Harris, F.; Mura, M.; Morton, L. H. G.; Zvelindovsky, A.; Phoenix, D. A., A Novel Form of Bacterial Resistance to the Action of Eukaryotic Host Defense Peptides, the Use of a Lipid Receptor. Biochemistry 2013, 52 (35), 60216029.

[89] Dennison, S. R.; Morton, L. H. G.; Harris, F.; Phoenix, D. A. In Use of the antimicrobial peptide, maximin H5 to protect against Staphyl;ococcus aureus, 5th International Meeting of Antimicrobial Peptides London, Chemistry, R. S. f., Ed. Royal Society for Chemistry: London, 2015; p 11.

[90] Dennison, S. R.; Mura, M.; Harris, F.; Morton, L. H. G.; Zvelindovsky, A.; Phoenix, D. A., The role of C-terminal amidation in the membrane interactions of the anionic antimicrobial peptide, maximin H5. Biochim. Biophys. Acta 2015, 1848 (5), 1111-1118.

[91] Lee, W. H.; Li, Y.; Lai, R.; Li, S.; Zhang, Y.; Wang, W., Variety of antimicrobial peptides in the Bombina maxima toad and evidence of their rapid diversification. Eur. J. Immunol. 2005, 35 (4), 1220-1229.

[92] Franco, O. L., Peptide promiscuity: an evolutionary concept for plant defense. FEBS Lett 2011, 585 (7), $995-1000$.

[93] Simmaco, M.; Severini, C.; De Biase, D.; Barra, D.; Bossa, F.; Roberts, J. D.; Melchiorri, P.; Erspamer, V., Six novel tachykinin- and bombesin-related peptides from the skin of the Australian frog Pseudophryne guntheri. Peptides 1990, 11 (2), 299-304.

[94] Ramos-Alvarez, I.; Moreno, P.; Mantey, S. A.; Nakamura, T.; Nuche-Berenguer, B.; Moody, T. W.; Coy, D. H.; Jensen, R. T., Insights into bombesin receptors and ligands: Highlighting recent advances. Peptides 2015, 72, $128-144$.

[95] Hallberg, M., Neuropeptides: Metabolism to Bioactive Fragments and the Pharmacology of Their Receptors. Med. Res. Rev. 2015, 35 (3), 464-519. 
[96] Spindel, E. R., Bombesin Peptides. In Handbook of Biologically Active Peptides (Second Edition), Kastin, A. J., Ed. Academic Press: Boston, 2013; pp 326-330.

[97] Severini, C.; Improta, G., Tachykinins. . In Handbook of Biologically Active Peptides (Second Edition), Kastin, A. J., Ed. Academic Press: Boston, 2013; pp 391-399.

[98] Gomes, A.; Giri, B.; Saha, A.; Mishra, R.; Dasgupta, S. C.; Debnath, A.; Gomes, A., Bioactive molecules from amphibian skin: Their biological activities with reference to therapeutic potentials for possible drug development. Indian $J$ Exp Biol. 2007, 45 (7), 579-593.

[99] Pukala, T. L.; Bowie, J. H.; Maselli, V. M.; Musgrave, I. F.; Tyler, M. J., Host-defence peptides from the glandular secretions of amphibians: structure and activity. Nat. Prod. Rep. 2006, 23 (3), 368-393.

[100] Dennison, S. R.; Harris, F.; Phoenix, D. A., Are oblique orientated alpha-helices used by antimicrobial peptides for membrane invasion? Protein peptide lett 2005, 12 (1), 27-29.

[101] Malik, E.; Dennison, S.; Harris, F.; Phoenix, D., pH Dependent Antimicrobial Peptides and Proteins, Their Mechanisms of Action and Potential as Therapeutic Agents. Pharmaceuticals 2016, 9 (4), 67.

[102] Lai, R.; Takeuchi, H.; Lomas, L. O.; Jonczy, J.; Rigden, D. J.; Rees, H. H.; Turner, P. C., A new type of antimicrobial protein with multiple histidines from the hard tick, Amblyomma hebraeum. FASEB J 2004. 18(12):1447-1449

[103] Francischetti, I. M.; Meng, Z.; Mans, B. J.; Gudderra, N.; Hall, M.; Veenstra, T. D.; Pham, V. M.; Kotsyfakis, M.; Ribeiro, J. M., An insight into the salivary transcriptome and proteome of the soft tick and vector of epizootic bovine abortion, Ornithodoros coriaceus. J Proteomics 2008, 71 (5), 493-512.

[104] Gulia-Nuss, M.; Nuss, A. B.; Meyer, J. M.; Sonenshine, D. E.; Roe, R. M.; Waterhouse, R. M.; Sattelle, D. B.; de la Fuente, J.; Ribeiro, J. M.; Megy, K.; Thimmapuram, J.; Miller, J. R.; Walenz, B. P.; Koren, S.; Hostetler, J. B.; Thiagarajan, M.; Joardar, V. S.; Hannick, L. I.; Bidwell, S.; Hammond, M. P.; Young, S.; Zeng, Q. D.; Abrudan, J. L.; Almeida, F. C.; Ayllon, N.; Bhide, K.; Bissinger, B. W.; Bonzon-Kulichenko, E.; Buckingham, S. D.; Caffrey, D. R.; Caimano, M. J.; Croset, V.; Driscoll, T.; Gilbert, D.; Gillespie, J. J.; Giraldo-Calderon, G. I.; Grabowski, J. M.; Jiang, D.; Khalil, S. M. S.; Kim, D.; Kocan, K. M.; Koci, J.; Kuhn, R. J.; Kurtti, T. J.; Lees, K.; Lang, E. G.; Kennedy, R. C.; Kwon, H.; Perera, R.; Qi, Y. M.; Radolf, J. D.; Sakamoto, J. M.; Sanchez-Gracia, A.; Severo, M. S.; Silverman, N.; Simo, L.; Tojo, M.; Tornador, C.; Van Zee, J. P.; Vazquez, J.; Vieira, F. G.; Villar, M.; Wespiser, A. R.; Yang, Y. L.; Zhu, J. W.; Arensburger, P.; Pietrantonio, P. V.; Barker, S. C.; Shao, R. F.; Zdobnov, E. M.; Hauser, F.; Grimmelikhuijzen, C. J. P.; Park, Y.; Rozas, J.; Benton, R.; Pedra, J. H. F.; Nelson, D. R.; Unger, M. F.; Tubio, J. M. C.; Tu, Z. J.; Robertson, H. M.; Shumway, M.; Sutton, G.; Wortman, J. R.; Lawson, D.; Wikel, S. K.; Nene, V. M.; Fraser, C. M.; Collins, F. H.; Birren, B.; Nelson, K. E.; Caler, E.; Hill, C. A., Genomic insights into the Ixodes scapularis tick vector of Lyme disease. Nat. Commun. 2016, 7, 13.

[105] Carnicelli, V.; Lizzi, A. R.; Ponzi, A.; Amicosante, G.; Bozzi , A.; Di Giulio, A., Interaction between antimicrobial peptides (AMPs) and their primary target, the biomembranes. In Microbial Pathogens and Strategies for Combating Them: Science, Technology and Education., Méndez-Vilas, A., Ed. Formatex Research Center.: Badajoz, Spain., 2013; Vol. 2, pp 1123-1134.

[106] Mura, M.; Dennison, S. R.; Zvelindovsky, A. V.; Phoenix, D. A., Aurein 2.3 functionality is supported by oblique orientated alpha-helical formation. Biochim Biophys Acta 2013, 1828 (2), 586-94.

[107] Phoenix, D. A.; Dennison, S. R.; Harris, F., Graphical Techniques to Visualize the Amphiphilic Structures of Antimicrobial Peptides. In Antimicrobial Peptides, Wiley-VCH Verlag GmbH \& Co. KGaA: 2013; pp 115-144.

[108] Lins, L.; Decaffmeyer, M.; Thomas, A.; Brasseur, R., Relationships between the orientation and the structural properties of peptides and their membrane interactions. Biochim Biophys Acta - Biomembranes 2008, 1778 (7-8), 1537-1544.

[109] Blijleven, J. S.; Boonstra, S.; Onck, P. R.; van der Giessen, E.; van Oijen, A. M., Mechanisms of influenza viral membrane fusion. Seminars in Cell \& Developmental Biology 2016, 60, 78-88.

[110] Phoenix, D. A.; Harris, F.; Mura, M.; Dennison, S. R., The increasing role of phosphatidylethanolamine as a lipid receptor in the action of host defence peptides. Prog Lipid Res 2015, 59, 26-37.

[111] Harris, F.; Dennison, S.; Phoenix, D. A., The prediction of hydrophobicity gradients within membrane interactive protein alpha-helices using a novel graphical technique. Protein peptide lett 2006, 13 (6), 595-600.

[112] Harris, F.; Daman, A.; Wallace, J.; Dennison, S. R.; Phoenix, D. A., Oblique orientated alpha-helices and their prediction. Curr Prot Peptid Sci 2006, 7 (6), 529-537.

[113] Monteiro, A. d. S.; Neto, W. R. N.; Mendes, A. R. S.; Pinto, B. L. d. S.; Silva, L. C. N. d.; Ferreira, G. F., Effects of Alterations in Staphylococcus aureus Cell Membrane and Cell Wall in Antimicrobial Resistance. In The Rise of Virulence and Antibiotic Resistance in Staphylococcus aureus, Enany, S.; Alexander, L. E. C., Eds. InTech: Rijeka, 2017 ; p Ch. 05.

[114] Joo, H.-S.; Otto, M., Mechanisms of resistance to antimicrobial peptides in staphylococci. Biochimt Biophys Acta Biomembranes 2015.

[115] Rehal, R. P.; Marbach, H.; Hubbard, A. T. M.; Sacranie, A. A.; Sebastiani, F.; Fragneto, G.; Harvey, R. D., The influence of mild acidity on lysyl-phosphatidylglycerol biosynthesis and lipid membrane physico-chemical properties in methicillin-resistant Staphylococcus aureus. Chem Phys Lipids 2017, 206, 60-70.

[116] Lai, Y.; Villaruz, A. E.; Li, M.; Cha, D. J.; Sturdevant, D. E.; Otto, M., The human anionic antimicrobial peptide dermcidin induces proteolytic defence mechanisms in staphylococci. Mol. Microbiol. 2007, 63 (2), $497-506$. 
[117] Wang, G.; Watson, K. M.; Peterkofsky, A.; Buckheit, R. W., Jr., Identification of Novel Human Immunodeficiency Virus Type 1-Inhibitory Peptides Based on the Antimicrobial Peptide Database. Antimicrob. Agents Chemother. 2010, 54 (3), 1343-1346.

[118] Sohlenkamp, C.; Geiger, O., Bacterial membrane lipids: diversity in structures and pathways. FEMS Microbiol Rev 2016, 40 (1), 133-159.

[119] de Kroon, A. I. P. M.; Rijken, P. J.; De Smet, C. H., Checks and balances in membrane phospholipid class and acyl chain homeostasis, the yeast perspective. Prog lipid res 2013, 52 (4), 374-394.

[120] Huarte, N.; Carravilla, P.; Cruz, A.; Lorizate, M.; Nieto-Garai, J. A.; Kräusslich, H.-G.; Pérez-Gil, J.; Requejo-Isidro, J.; Nieva, J. L., Functional organization of the HIV lipid envelope. Scientific reports 2016, 6, 34190.

[121] Williamson, P.; Schlegel, R. A., Back and forth: the regulation and function of transbilayer phospholipid movement in eukaryotic cells. Mol Membr Biol 1994, 11 (4), 199-216.

[122] Marconescu, A.; Thorpe, P. E., Coincident exposure of phosphatidylethanolamine and anionic phospholipids on the surface of irradiated cells. Biochim Biophys Acta 2008, 1778 (10), 2217-24.

[123] Lohner, K.; Prenner, E. J., Differential scanning calorimetry and X-ray diffraction studies of the specificity of the interaction of antimicrobial peptides with membrane-mimetic systems. Biochim Biophys Acta 1999, 1462 (1-2), 141-156.

[124] Dennison, S. R.; Harris, F.; Phoenix, D. A., The interactions of aurein 1.2 with cancer cell membranes. Biophysl Chem 2007, $127(1-2), 78-83$.

[125] Merchant, T. E.; Diamantis, P. M.; Lauwers, G.; Haida, T.; Kasimos, J. N.; Guillem, J.; Glonek, T.; Minsky, B. D., Characterisation of malignant colon tumors with P-31 nuclear magnetic resonance phospholipid and phosphatic metabolite profiles. Cancer 1995, 76 (10), 1715-1723.

[126] Merchant, T. E.; Meneses, P.; Gierke, L. W.; Denotter, W.; Glonek, T., P-31 Magnetic-resonance phospholipid profiles of neoplastic human breast tissues. Brit J Cancer 1991, 63 (5), 693-698.

[127] Todor, I. N.; Lukyanova, N. Y.; Chekhun, V. F., The lipid content of cisplatin- and doxorubicin-resistant MCF-7 human breast cancer cells. Exp Oncol 2012, 34 (2), 97-100.

[128] Mader, J. S.; Hoskin, D. W., Cationic antimicrobial peptides as novel cytotoxic agents for cancer treatment. Expert Opin Investig Drugs 2006, 15 (8), 933-46.

[129] Hoskin, D. W.; Ramamoorthy, A., Studies on anticancer activities of antimicrobial peptides. Biochim Biophys Acta 2008, $1778(2), 357-75$.

[130] Prabhu, S.; Dennison, S. R.; Mura, M.; Lea, R. W.; Snape, T. J.; Harris, F., Cn-AMP2 from green coconut water is an anionic anticancer peptide. J Peptid Sci 2014, 20 (12), 909-915.

[131] Dennison, S. R.; Harris, F.; Phoenix, D. A., The interactions of aurein 1.2 with cancer cell membranes. Biophys Chem 2007, 127 (1-2), 78-83.

[132] Dennison, S. R.; Wallace, J.; Harris, F.; Phoenix, D. A., Amphiphilic alpha-helical antimicrobial peptides and their structure/function relationships. Protein Peptide Lett 2005, 12 (1), 31-39.

[133] White, S. H.; Wimley, W. C., Membrane protein folding and stability: Physical principles. Annu Rev Biophys Biomol Struct 1999, 28, 319-365.

[134] Fujii, G., To fuse or not to fuse: the effects of electrostatic interactions, hydrophobic forces, and structural amphiphilicity on protein-mediated membrane destabilization. Adv. Drug Deliv. Rev. 1999, 38 (3), 257-277.

[135] Frederick, H.; Sarah, R. D.; David, A. P., Anionic Antimicrobial Peptides from Eukaryotic Organisms and their Mechanisms of Action. Curr Chem Biol 2011, 5 (2), 142-153.

[136] Chu, H. T.; Pazgier, M.; Jung, G.; Nuccio, S. P.; Castillo, P. A.; de Jong, M. F.; Winter, M. G.; Winter, S. E.; Wehkamp, J.; Shen, B.; Salzman, N. H.; Underwood, M. A.; Tsolis, R. M.; Young, G. M.; Lu, W. Y.; Lehrer, R. I.; Baumler, A. J.; Bevins, C. L., Human alpha-Defensin 6 Promotes Mucosal Innate Immunity Through Self-Assembled Peptide Nanonets. Science 2012, 337 (6093), 477-481.

[137] Wu, X.; Li, Z.; Li, X.; Tian, Y.; Fan, Y.; Yu, C.; Zhou, B.; Liu, Y.; Xiang, R.; Yang, L., Synergistic effects of antimicrobial peptide DP7 combined with antibiotics against multidrug-resistant bacteria. Drug Des Devel Ther 2017, 11, 939946.

[138] Almaaytah, A.; Alnaamneh, A.; Abualhaijaa, A.; Alshari', N.; Al-Balas, Q., In Vitro Synergistic Activities of the Hybrid Antimicrobial Peptide MelitAP-27 in Combination with Conventional Antibiotics Against Planktonic and Biofilm Forming Bacteria. Int J Pept Res Ther 2016, 22 (4), 497-504.

[139] Bollenbach, T., Antimicrobial interactions: mechanisms and implications for drug discovery and resistance evolution. Curr Opin Microbiol 2015, 27 (Supplement C), 1-9.

[140] Coates, A.; Hu, Y., Conventional Antibiotics - Revitalized by New Agents. In Novel Antimicrobial Agents and Strategies, Wiley-VCH Verlag GmbH \& Co. KGaA: 2014; pp 17-30.

[141] Brown, D., Antibiotic resistance breakers: can repurposed drugs fill the antibiotic discovery void? Nat. Rev. Drug Discov. 2015, 14 (12), 821-32.

[142] Kummer, M. P.; Heneka, M. T., Truncated and modified amyloid-beta species. Alzheimers Res Ther 2014, 6 (3), 28. 
[143] Mankar, S.; Anoop, A.; Sen, S.; Maji, S. K., Nanomaterials: amyloids reflect their brighter side. Nano Rev 2011, 2 , 10.3402/nano.v2i0.6032.

[144] Gour, S.; Kaushik, V.; Kumar, V.; Bhat, P.; Yadav, S. C.; Yadav, J. K., Antimicrobial peptide (Cn-AMP2) from liquid endosperm of Cocos nucifera forms amyloid-like fibrillar structure. J Peptid Sci 2016, 22 (4), 201-207.

[145] Kim, S.; Kim, J. H.; Lee, J. S.; Park, C. B., Beta-Sheet-Forming, Self-Assembled Peptide Nanomaterials towards Optical, Energy, and Healthcare Applications. Small 2015, 11 (30), 3623-3640.

[146] Marcotte, I.; Wegener, K. L.; Lam, Y.-H.; Chia, B. C. S.; de Planque, M. R. R.; Bowie, J. H.; Auger, M.; Separovic, F., Interaction of antimicrobial peptides from Australian amphibians with lipid membranes. Chem Phys Lipids 2003, 122 (1-2), 107-120.

[147] Hede, K., An infectious arms race. Nature 2014, 509 (7498), S2-S3.

[148] Hullin-Matsuda, F.; Makino, A.; Murate, M.; Kobayashi, T., Probing phosphoethanolamine-containing lipids in membranes with duramycin/cinnamycin and aegerolysin proteins. Biochimie 2016, 130, 81-90.

[149] Henriques, S. T.; Huang, Y.-H.; Castanho, M. A. R. B.; Bagatolli, L. A.; Sonza, S.; Tachedjian, G.; Daly, N. L.; Craik, D. J., Phosphatidylethanolamine Binding Is a Conserved Feature of Cyclotide-Membrane Interactions. J Biol Chem 2012, 287 (40), 33629-33643.

[150] Matthijs, S.; Hernalsteens, J.-P.; Roelants, K., An orthologue of the host-defense protein psoriasin (S100A7) is expressed in frog skin. Dev Comp Immunol 2017, 67, 395-403.

[151] Torre, L. A.; Bray, F.; Siegel, R. L.; Ferlay, J.; Lortet-Tieulent, J.; Jemal, A., Global Cancer Statistics, 2012. CA Cancer J Clin.s 2015, 65 (2), 87-108.

[152] Ferlay, J.; Shin, H. R.; Bray, F.; Forman, D.; Mathers, C.; Parkin, D. M., Estimates of worldwide burden of cancer in 2008: GLOBOCAN 2008. Int J Cancer 2010, 127 (12), 2893-917.

[153] Oelkrug, C.; Hartke, M.; Schubert, A., Mode of Action of Anticancer Peptides (ACPs) from Amphibian Origin. Anticancer Res 2015, 35 (2), 635-643.

[154] Apponyi, M. A.; Pukala, T. L.; Brinkworth, C. S.; Maselli, V. M.; Bowie, J. H.; Tyler, M. J.; Booker, G. W.; Wallace, J. C.; Carver, J. A.; Separovic, F.; Doyle, J.; Llewellyn, L. E., Host-defence peptides of Australian anurans: structure, mechanism of action and evolutionary significance. Peptides 2004, 25 (6), 1035-54.

[155] Dennison, S. R.; Whittaker, M.; Harris, F.; Phoenix, D. A., Anticancer alpha-helical peptides and structure/function relationships underpinning their interactions with tumour cell membranes. Curr Prot Peptid Sci 2006, 7 (6), 487-499.

[156] Harris, F.; Dennison, S. R.; Singh, J.; Phoenix, D. A., On the selectivity and efficacy of defense peptides with respect to cancer cells. Med resh rev 2013, 33 (1), 190-234.

[157] Gaspar, D.; Veiga, A. S.; Castanho, M. A. R. B., From antimicrobial to anticancer peptides. A review. Front Microbiol 2013, 4, 294.

[158] Cancer: The global burden of cancers attributable to infections. Nat Rev Gastroenterol Hepatol 2012, 9 (7), 364-364.

[159] Plummer, M.; de Martel, C.; Vignat, J.; Ferlay, J.; Bray, F.; Franceschi, S., Global burden of cancers attributable to infections in 2012: a synthetic analysis. The Lancet Global Health.

[160] Shigehara, K.; Sasagawa, T.; Namiki, M., Human papillomavirus infection and pathogenesis in urothelial cells: A mini-review. J Infect Chemother 2014, 20 (12), 741-747.

[161] D'Souza, G.; Dempsey, A., The role of HPV in head and neck cancer and review of the HPV vaccine. Prev. Med 2011, 53, S5-S11.

[162] De Flora, S.; La Maestra, S., Epidemiology of cancers of infectious origin and prevention strategies. J Prev Med Hyg. 2015, 56 (1), E15-E20.

[163] Crosbie, E. J.; Einstein, M. H.; Franceschi, S.; Kitchener, H. C., Human papillomavirus and cervical cancer. Lancet 2013, 382 (9895), 889-99.

[164] Dostalova, S.; Milosavljevic, V.; Guran, R.; Kominkova, M.; Cihalova, K.; Kopel, P.; Vaculovicova, M.; Adam, V.; Kizek, R., Antiviral activity of fullerenes modified with maximin H5 derivaties. Mendelnet 2015 2015, 579-584.

[165] Dostalova, S.; Moulick, A.; Milosavljevic, V.; Guran, R.; Kominkova, M.; Cihalova, K.; Heger, Z.; Blazkova, L.; Kopel, P.; Hynek, D.; Vaculovicova, M.; Adam, V.; Kizek, R., Antiviral activity of fullerene C60 nanocrystals modified with derivatives of anionic antimicrobial peptide maximin H5. Monatshefte für Chemie - Chemical Monthly 2016, 147 (5), 905-918.

[166] Secor, P. R.; Sweere, J. M.; Michaels, L. A.; Malkovskiy, A. V.; Lazzareschi, D.; Katznelson, E.; Rajadas, J.; Birnbaum, M. E.; Arrigoni, A.; Braun, K. R.; Evanko, S. P.; Stevens, D. A.; Kaminsky, W.; Singh, P. K.; Parks, W. C.; Bollyky, P. L., Filamentous Bacteriophage Promote Biofilm Assembly and Function. Cell Host Microbe 2015, 18 (5), 549-559. 